\title{
Tekmeria
}

Vol 14 (2018)

$(2017-2018)$

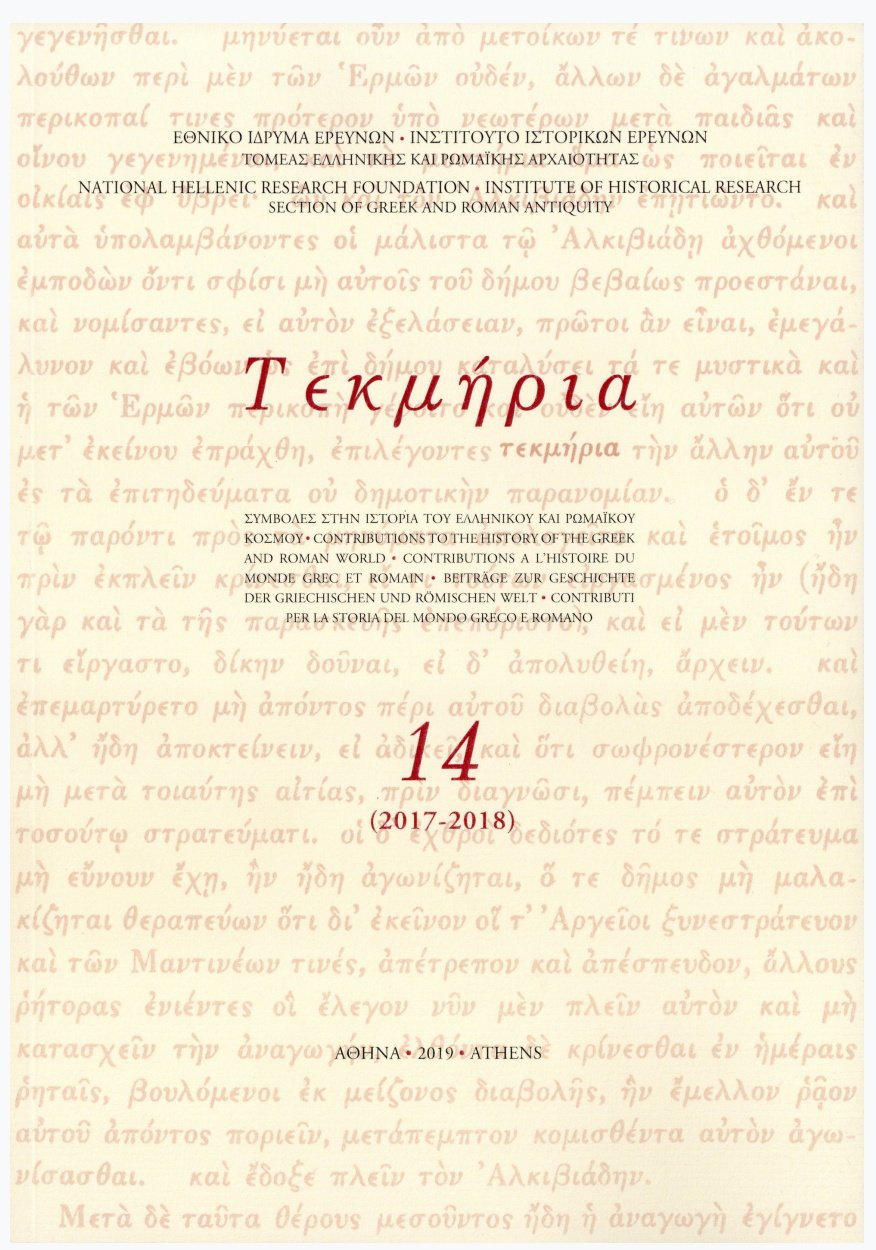

\section{A Roman financier's Version of Euergetism: C. Vibius Salutaris and Ephesos}

Christina Kokkinia

doi: $\underline{10.12681 / \text { tekmeria.17405 }}$

Copyright () 2019, Christina Kokkinia

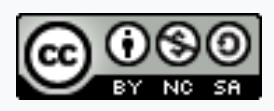

This work is licensed under a Creative Commons Attribution-NonCommercialShareAlike 4.0.

\section{To cite this article:}

Kokkinia, C. (2019). A Roman financier's Version of Euergetism: C. Vibius Salutaris and Ephesos. Tekmeria, 14, 215-252. https://doi.org/10.12681/tekmeria.17405 


\section{CHRISTINA KOKKINIA}

\section{A Roman Financier's Version of Euergetism: C. Vibius Salutaris and Ephesos}

The large epigraphic dossier IEph 1a 27 is our source for C. Vibius Salutaris' gifts to the city of Ephesos in $104 \mathrm{CE}$. On the evidence of these inscriptions, historians have debated the importance of Salutaris' foundation for the city's cultural and religious identity and have assigned Vibius Salutaris a place among the most important civic benefactors known to us. This paper argues, on epigraphic evidence and contrary to a widely held view, that Salutaris' family had no connection to Ephesos; that the terms of his foundation gave him absolute control over the foundation's capital; that the objects donated and the rituals in which they featured were so designed as to bestow disproportionately great honor on the founder; and finally, that Salutaris' gifts to Ephesos would most likely have sunk in oblivion, were it not for his connections to representatives of the Roman state, and for his foundation's successful advertising of Ephesos' attachment to Rome.

\section{Overview}

In the winter of 1866, the English architect John Turtle Wood was at the site of ancient Ephesos. He was determined to find the Artemision but, having failed to locate it despite digging for three years, his funding was in danger. He needed artefacts that he could send back to the British Museum to persuade that institution to continue to sponsor his research. ${ }^{1}$ So he turned to Ephesos' theatre, where he found "the whole of the eastern wall" of the entrance "inscribed with a series of decrees". ${ }^{2}$ Wood had found the now famous epigraphic dossier of Vibius Salutaris, dated $104 \mathrm{CE}$, in situ, on the right flank of the south entrance at Ephesos' theatre. In his book Discoveries at Ephesos (1877) he describes the contents of the inscriptions, and he includes a publication of the texts in an appendix.

1. Wood 1877, vii.

2. Wood took "all the inscriptions and sculpture that were worth sending to England" that he found scattered on the stage of the theatre (Wood 1877, 70). But, he wrote, "there was a much greater prize awaiting my discovery" when he "came to clear the southern entrance" (Wood 1877, 73).

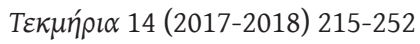


Wood took the inscribed blocks down from the wall and sent them to London, where they are still today. Some of the stones were damaged in the process and some pieces broke away. Since he had made only a hasty sketch of the inscriptions as he found them, Wood's reconstruction of the dossier was inaccurate. In an effort to address these problems, the Austrian epigraphist Rudolph Heberdey discovered new inscribed fragments belonging to the Salutaris dossier at Ephesos' theatre, and studied the texts closely. ${ }^{3}$ Heberdey's edition, published in 1912, was adopted with small changes by the editors of Inschriften von Ephesos (1979). IEph 1a 27 has remained the edition of reference since and it is the edition used in this paper. ${ }^{4}$

In Heberdey's reconstruction, the Salutaris dossier consists of 568 lines of text and displays seven documents:

A: an honorary decree for Salutaris (1l. 1-133)

B: a document termed "disposition" ( $\delta\left\llcorner\alpha \dot{\alpha} \alpha \xi\left\llcorner\varsigma^{5}\right)\right.$ (1l. 134-332)

3. Heberdey 1912, 127. Both Heberdey and Wood's German colleague Friedrich Adler express their exasperation with Wood's methods. In his book on the theatre of Ephesos, Heberdey writes: "Da es ihm aber nur darauf ankam, durch Einzelfunde vom British Museum weitere Geldbeiträge zu erlangen, begnügte er sich damit, den Trümmerhaufen nach Skulpturen und Inschriften zu durchwühlen, wobei er die Blöcke von Nord nach Süd durcheinander wälzte und scheute sich selbst nicht, die großenteils noch im alten Verbande befindlichen Quadern der Südparodoswand mit der großen Salutarisinschrift gewaltsam zu entfernen" (Heberdey 1912, 2; cf. Heberdey 1912, 3: F. Adler on Wood having left behind "ein unbeschreibliches Chaos von Bruchstücken"). Heberdey on Wood's copies: "Im allgemeinen heutigen Anforderungen nur in geringem Grade entsprechend und von Leserfehlern voll, haben sie doch mehrfach einzelne Buchstaben, einmal sogar eine größere Partie (Z. 383 ff.) erhalten, die beim Transporte der Steine absplitterten und verloren gegangen sind" (Heberdey 1912, 127).

4. The text of F.H. Marshall in the fourth volume of the series Greek Inscriptions in the British Museum (Marshall 1916), no. 481* is identical with Heberdey's text and replaces E.L. Hicks' edition in the same series, vol. III (1890), no. 481, that was based on Wood's text. The most widely read and cited work on this dossier is Rogers 1991, which discusses certain aspects of Salutaris' foundation and includes an English translation based on the text of IEph 1a 27.

5. The document is referred to in the inscriptions of the dosssier by this term, attested several times, i.a. in 1l. 139-140 of document B (partly preserved); 11. 68, 73 (11. 93, 105, 109 restored) of document A. 
C: a letter from the proconsul C. Aquillius Proculus (11. 333-369)

D: a letter from Proculus' legate, P. Afranius Flavianus (11. 370-413)

E and F: two short decrees of the Ephesian council (1l. 414-430 and 431-446)

G: an additional "disposition" ( $\delta\left\llcorner\alpha \dot{\tau} \tau \xi_{\zeta \zeta}\right)$ (ll. 447-568)

The texts were distributed in six columns of increasing height, from $2 \mathrm{~m}$ on the left to $4.3 \mathrm{~m}$ on the right. ${ }^{6}$ The documents, all dated in the same year by mention of the Roman consuls ${ }^{7}$ and by mention of the holder of the Ephesian prytany, ${ }^{8}$ all concern the donations of a man named C. Vibius Salutaris, a Roman knight, Ephesian citizen, and member of the Ephesian council. He is unknown to us outside Ephesos.

Salutaris' donations include sculptures and money: thirty-one portraits and representations of civic bodies, and money for lotteries and distributions. The majority of the donated sculptures were to be kept at the Artemision and to be carried in procession from that temple to the theatre and back, on several occasions throughout the year. The donations of money were to be used for distributions and lotteries among the members of various civic bodies once a year on the birthday of the goddess.

Most striking among the details of these donations is the frequency of the processions. They were to take place before and after all assembly meetings and (apparently) all agonistic events. ${ }^{9}$ By one estimate, this means that the

6. See the reconstruction sketch, IEph 1a, p. 169.

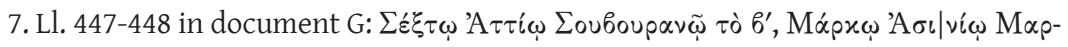

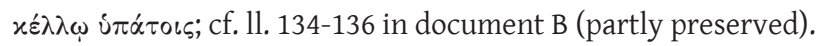

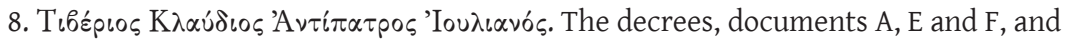
the epistles, documents C and D, are dated by the prytany; Salutaris' two "dispositions", documents $B$ and $G$, are dated both by the prytany and the Roman consuls.

9. Before and after all assembly meetings and agonistic events: 11. 202-214 (fragmentary); 11. 554-568 (preserved). The only somewhat detailed and reasonably well-preserved passage relating to the frequency of the processions is 11. 52-56 in document A:

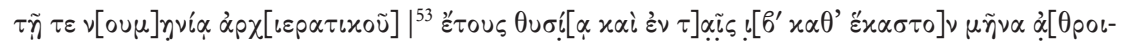

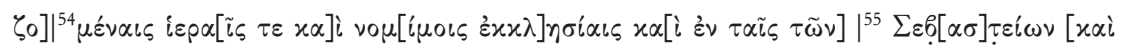

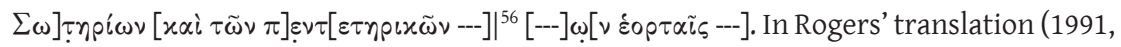
155): "during the first new moon's sacrifice of the archieratic year, and on the occasions of the twelve sacred gatherings and regular assemblies every month, and during the Sebasteia and the Soteria and the penteteric festivals". The number of the ekklesiai 
sculptures donated by Salutaris would be paraded through the city streets at least twice a month throughout the year. ${ }^{10}$

During those parades, temple officials would be joined by the ephebes in carrying nine groups of statues. ${ }^{11}$ Each one of those groups would include a statue of Artemis and two other statues. In some cases, the two statues joining the Artemis in each triad merged Greek and Roman symbolism, as, for example, when a personification of the Roman senate was paired with a personification of the council of Ephesos, or a personification of the ordo equester with one of the ephebeia. Others included mythical founders of the city and personifications of the Ephesian tribes: ${ }^{12}$

(1. 54) is not in fact preserved. Rather, $\iota b^{\prime}$ and $x \alpha \theta^{\prime} \varepsilon^{\prime} x \alpha \sigma \tau o \nu(\mu \tilde{\eta} \nu \alpha)$ have been restored by Heberdey in 1.53 (Heberdey 1912, 142). Ll. 202-204 in document B seem to have contained a similar passage, but they are much more fragmentary. Other references are summary: 1. 157: $\tau i \theta \varepsilon[\sigma] \theta \alpha \iota$ ह่ $\tau \alpha \tilde{\iota} \varsigma$ ह̇ $\varkappa \varkappa \lambda \eta \sigma i \alpha \iota \varsigma$ (be placed during the assemblies); 1.420

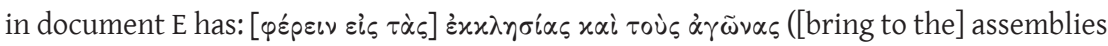

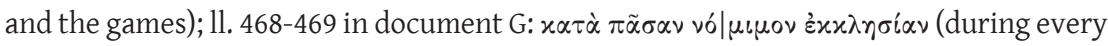

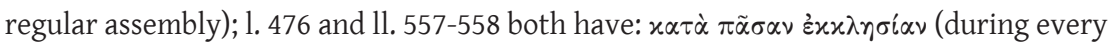
assembly).

10. Rogers 1991, 83.

11. Ll. 48-50 in document A must have contained a reference to those who would carry the statues in the processions, but these lines are very fragmentary. The ephebes, however, are securely attested in 1. 50. Above 1. 48, 17 lines are almost completely lost. In 1. 204, if Heberdey's restoration is correct, those who carried the statues are mentioned simply as oi $x \alpha \theta \dot{\eta} x o v \tau \varepsilon \varsigma$ ([i்] ò $\tau \tilde{\omega} \nu \varkappa \alpha[\theta \eta x o ́ v \tau \omega \nu])$ "by the fitting people", as translated in Rogers 1991, 163. The editors of IEph print Heberdey's restoration in 1. 204, but they omit the phrase in their translation: "(Die genannten) Statuenkopien (sollen) während (jeder regulären) Volksversammlung (und zur Zeit des) Neumond(opfers) des archieratischen (Jahres -d.h. am 1. Januar-) im (Theater) von den ... (auf den nach Blocks verteilten) und mit einer Aufschrift versehenen neun Basen (in Dreiergruppen aufgestellt werden ...)" (IEph 1a, p. 211). The two decrees of the Ephesian council, documents $\mathrm{E}$ and F, assign to the chrysophorountes and the neopoioi, aided by the ephebes, the carrying of the statues (document E) and assign the chrysophorountes places in the theatre (document F).

12. In document A, 11. 22ff. (the end of the passage is lost) give a summary account of the sculptures promised, in which the sculptures are grouped, first, according to their precious metal and, second, according to their theme: the passage lists one 
The groups are listed in Salutaris' "disposition" ( $\delta\left\llcorner\alpha \dot{\tau} \tau \alpha \xi_{\iota \zeta}\right)$, document B..$^{13}$ The leading triad would consist of an Artemis with representations of the Roman senate and the council of Ephesos (1l. 158-164), followed by an Artemis with the Roman people and the Ephesian gerousia (1l. 164-167). The third group would include a specific type of Artemis, "similar to the one in the exedra of the ephebes", ${ }^{14}$ together with representations of the ordo equester and the ephebeia (11. 168-173). The fourth group would be an Artemis with Augustus and the Ephesian tribe Sebaste (1l. 173-177). The fifth group would be an Artemis with the demos of the Ephesians and the tribe of the Ephesians (1l. 177-181). The sixth group would include an Artemis, possibly Androklos,${ }^{15}$ the hero and first mythical founder of Ephesos, and the tribe of the Karenaioi (1l. 182-186). The seventh group would consist of an Artemis with Lysimachos and the tribe of the Teioi (1l. 186-189). The eighth group would be an Artemis with another mythical founder, Euonymos, and the tribe of the Euonymoi (ll. 189-193). Finally, there would be an Artemis with a representation of Mount Pion and the tribe of the Bembinaioi (1l. 194-198).

Salutaris' $\delta \dot{\alpha}^{\prime} \tau \alpha \xi_{L \zeta}$, then, placed at the head of the parade the council of Ephesos -that is, the civic body to which Salutaris himself belonged-grouped

golden $\alpha \dot{\pi} \varepsilon\left\llcorner x^{\prime} v \iota \mu \alpha\right.$ including some gilded silver figures (an Artemis with two deer, as is specified in 1l. 159-160); eight silver $\dot{\alpha} \pi \varepsilon \iota x o v i \sigma \mu \alpha \tau \alpha$, also of Artemis (though this is not stated, it follows from what is said in this decree concerning Salutaris' devotion to the goddess in the passage immediately preceding this one); 20 silver sixóvec, five with

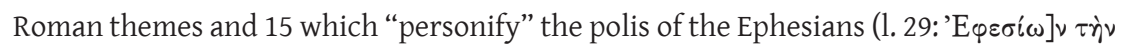
$\pi \dot{c} \lambda \iota \nu \pi \rho \circ \sigma[\omega \pi \circ \pi \circ\llcorner\circ v \sigma \alpha \varsigma])$. Ll. 158-197 in Salutaris' “diataxis", document B, by contrast, list the statues in groups of three, as they would be placed on seven bases at the theatre. I assume that the order of the triads, as they are listed in document B, was also the order in which the sculptures were to be paraded. On sixìv and $\dot{\alpha} \pi \varepsilon \iota x o ́ v \iota \sigma \mu \alpha$, see the Appendix.

13. Many of the relevant passages in document B are very fragmentarily preserved and have been restored based on the inscriptions IEph 1a 28-35, discussed below (pp. 237-238).

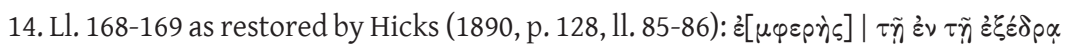
$\tau \tilde{\omega} \nu \dot{\varepsilon} \varphi \dot{\eta} b \omega \nu$.

15. The restoration of the name of Androklos has been suggested by R. Merkelbach. It seems plausible although only an omicron survives from this name in 1.18 of IEph 1a 30; see IEph 1a, p. 181 n. 183, cf. p. 230 n. 18. 
with its Roman equivalent, the Roman senate. There followed another two groups pairing Ephesian civic institutions with Roman counterparts; then came a group representing the most recently created Ephesian tribe together with the Roman emperor after whom that tribe was named. The older Ephesian tribes were represented from the middle to the rear of the parade. ${ }^{16}$ While discussing the details of this arrangement is beyond the scope of this paper, it should be noted that Salutaris' partly idiosyncratic choices suggest that the order of his parade was likely prescriptive rather than descriptive: the parade was a reflection of Salutaris' political views and wishes, not necessarily a faithful reproduction of the actual roles and functions of the Ephesian civic bodies. ${ }^{17}$

The statue triads in brief:

1. Artemis, the Roman senate, the council of Ephesos

2. Artemis, the Roman people, the Ephesian gerousia

3. Artemis of the ephebes, the ordo equester, the ephebeia

4. Artemis, Augustus, the Ephesian tribe Sebaste

5. Artemis, the Ephesian demos, the tribe of the Ephesians

6. Artemis, Androklos (?), the tribe of the Karenaioi

7. Artemis, Lysimachos, the tribe of the Teioi

8. Artemis, Euonymos, the tribe of the Euonymoi

9. Artemis, Mount Pion, the tribe of the Bembinaioi

These statues, 27 in number, would be carried from the Artemision to the theatre and would be placed there for the duration of the assemblies and the games. After each meeting and agonistic event, in what might be called today a closing ceremony of those events, the statues would be carried back to the temple.

The route to be followed by the procession on its way to the theatre and back is defined in the extant documents, and from that description it is apparent that the statues were to be carried back to the temple by a different

16. On the Ephesian tribes and the tribes in Greek cities of the Roman Empire in general, see Kunnert 2012.

17. Salutaris' surprising choice of pairing the Ephesian gerousia with the Roman people has been noticed and discussed by Giannakopoulos $(2008,217)$ and Bauer $(2014$, 212). See below, p. 245, on the pair Ephesian epheboi - Roman ordo equester. 
route, so that the two processions, at the beginning and at the end of each occasion, traced a circle along the city's main streets. ${ }^{18}$

The 27 statues do not, however, form the sum total of Salutaris' donations of sculptures. The list of statues in Salutaris' $\delta \iota \alpha$ ' $\tau \xi_{\iota \varsigma}$, document B, included 29 statues and was headed by a group that did not include an Artemis, but consisted instead of a statue of the emperor Trajan and a statue of his wife Plotina. These, however, would not feature in the processions, nor would they be kept at the Artemision. Salutaris donated the statues of the reigning couple with the stated intention of keeping them himself. Only after Salutaris' death would the two statues be given to the city, to be included in future processions. ${ }^{19}$ Yet another pair of statues did not form part of Salutaris' original foundation. A statue of Athena Pammousos ("Athena of all Muses") and a statue of Sebaste Homonoia ("Augustan Concordia") were donated as an additional bequest, known to us from the last document of the dossier. Athena and Homonoia were to be paraded along with the nine statuary triads. In the case of these two statues, however, Salutaris donated an amount of silver for silver-coating their two bases. ${ }^{20}$ The processions, then, carried 29 statues, and, when they reached the theatre, placed 27 of them on stone bases and two on silver-coated ones.

\section{Vibius Salutaris}

Who was the man who founded these processions? With near certainty, Vibius Salutaris, the Roman knight, was not an Ephesian, though it is widely assumed that he was. ${ }^{21}$ The erroneous assumption is based on a passage of the Salutaris dossier that, supposedly, mentioned his father.

18. Weiss 2012, 54-61, and Graf 2015, 44-46, discuss the purpose of this circular movement.

19. See 1l. 152-158, discussed below, pp. 233-235.

20. Ll. 466 and 472.

21. Rogers $(1991,16)$ postulates that Salutaris' father was already well known at Ephesos in $104 \mathrm{CE}$, and Rogers' interpretation of the foundation as a means of defending Hellenic culture against Roman influence requires that the family was well established at Ephesos. Rogers sees the foundation as a medium through which the city "asserted a particular civic identity" in the face of the "subtle social and theological challenge to the Ephesians' sense of the basic Greek character of their city" posed by Roman influence: Rogers 1991, 140-141 and passim. R. Hanslik, the author of the RE lemma on Vibius Salutaris (Vibius 51 in Hanslik 1958), by contrast, was guessing in the right direction 
Eight lines in the first document of the dossier, a decree of the council and the people of Ephesos honoring Salutaris for his donations, contain the sole reference to Salutaris' background and to his past up to the moment when he proposed his donation:

Honorary decree (document A) of the boule and demos of Ephesos for Salutaris, IEph 1a 27, 11. 14-22:

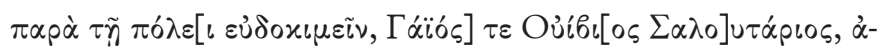

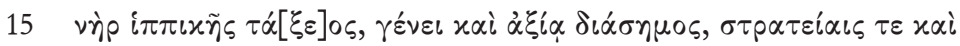

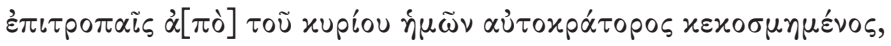

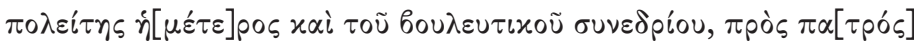

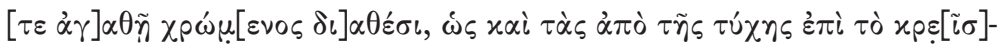

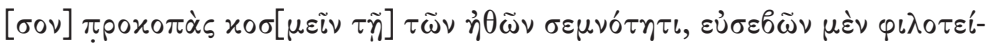

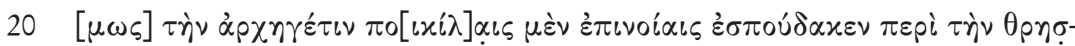

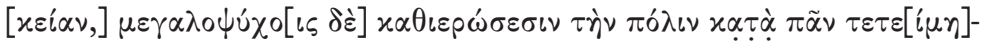

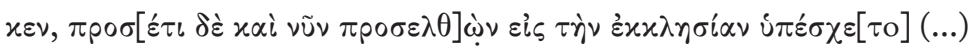

We learn from this passage that Salutaris belonged to the Roman ordo

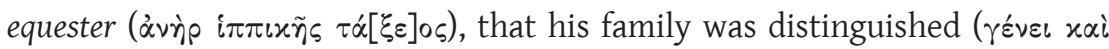
$\dot{\alpha} \xi i \alpha \delta \delta \dot{\alpha} \sigma \eta \mu \circ \varsigma)$, that he had been assigned military and procuratorial posts by

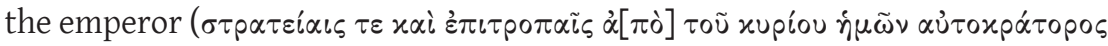

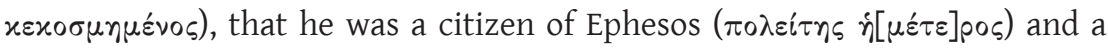

when he saw in Vibius Salutaris an Italian. Cf. Quaß 1982, 200. Under the influence of Rogers' book this possibility has been neglected, although reviewers had expressed doubts about Rogers' interpretation in general: Spawforth 1992; van Bremen 1993, with a well-founded refutation of Rogers' basic assumption that "we see here the mind of the Ephesian demos at work" (van Bremen 1993, 246); cf. Hoskins Walbank 1994. Their critique, however, did not draw on epigraphic evidence. Ameling $(1993,725)$ doubts the security of certain restorations concerning the sums donated and their recipients but does not comment on Salutaris' origin or status. Hoskins Walbank pointed to Salutaris' Roman tribe, Oufentina, an indication that he was in fact an Italian (Hoskins Walbank 1994, 90; cf. already Dessau, although another argument of his against Salutaris' Ephesian origin was uncharacteristically weak: he expected explicit mention of this fact in the inscriptions; Dessau 1910, 17 n. 1). White $(1995,63)$ and Smith $(2006,426)$ have considered the possibility that "Salutaris' family had conceivably settled quite recently" at Ephesos (Smith), although, again, without citing epigraphic evidence. 


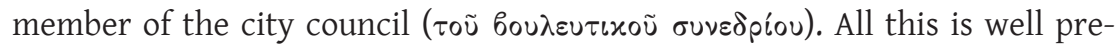
served, with only a few missing letters in each line, which have, for the most part, been securely restored.

By contrast, the few letters missing at the end of line 17 have caused confusion. This is surprising, because the restoration $\pi$ pòs $\pi \alpha[\tau$ pòs] in $\pi$ pò $\varsigma \pi \alpha[\tau \rho o ́ \varsigma \mid$ $\tau \varepsilon \dot{\alpha} \gamma] \alpha \theta \tilde{\eta} \chi \rho \omega \dot{\mu} \mu[\varepsilon v \circ \varsigma \delta \iota] \alpha \theta \dot{\varepsilon} \sigma \iota$, which is found in every edition of this text, and to my knowledge has never been doubted, is unprecedented and wrong. Пpòs

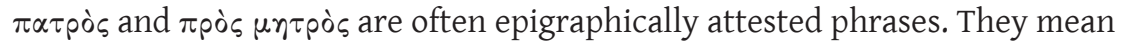
"on the side of the (his, her) father" and "on the side of the (his, her) mother". Translated in accordance with the common meaning of $\pi \rho \dot{s} \varsigma \pi \alpha \tau \rho \grave{s} /$

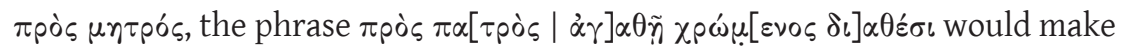
no sense: "displaying a good disposition on the side of his father". Therefore scholars have translated the phrase freely. ${ }^{22}$

The search for a meaningful translation of this passage, as it is restored, is, however, unnecessary. Expressions similar to $\alpha \gamma \alpha \theta \tilde{\eta} \chi \rho \omega \dot{\mu} \mu \varepsilon v \circ \varsigma \delta \iota \alpha \theta \varepsilon$ c $\sigma$, al-

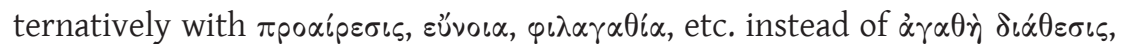
are common in honorary decrees and letters of recommendation and they do not relate to ancestors and family members. Such expressions, as a rule, refer

22. The editors of IEph translated "schon vom Vater her von guter Art". Rogers translates "regulating his life well, as his father did". That the son is as virtuous as the father is something we see in honorary decrees: the father is mentioned first and then the son is said to be as virtuous as the father. Salutaris' father, however, is not spoken of in the preceding lines. Possibly (one must guess because the phrase is not discussed in these publications) the translations in IEph and Rogers may be based on a much rarer use of $\pi$ pòs with genitive, LSJ s.v. $\pi$ pós A.IV. "of that which is derivable from: hence, agreeable to, becoming, like". If so, they assume a use of $\pi$ pòs with genitive that is both rare in general and unattested among the many epigraphic examples of $\pi$ pòs $\pi \alpha \tau$ pòs and $\pi \rho \grave{s} \varsigma$

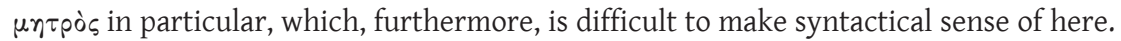
Had the genitive $\pi \alpha \tau$ pòs been on the stone, as opposed to having been restored by the

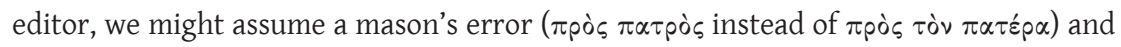
might interpret this as "displaying a good disposition towards his father", though honorary decrees for benefactors do not usually include references to how father-friendly the honorand was. (Unless, of course, we are dealing with Hellenistic kings, who may be praised as philopatores.) Similarly, the translations of IEph and Rogers would be correct if

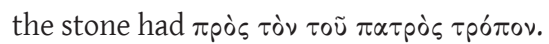


instead to the rest of the citizens, with vocabulary meaning everyone, the city as a whole, all citizens, all people. ${ }^{23}$

The letters missing at the end of line 17, therefore, formed, with near certainty, the second syllable of the accusative $\pi \dot{\alpha} \nu \tau \alpha \varsigma$. As in many similar texts, Salutaris is said here to have been kind to everyone: $\pi \rho \grave{s} \pi \dot{\alpha}[\nu \tau \alpha \varsigma \mid \dot{\alpha} \gamma] \alpha \theta \tilde{\eta}$ $\chi \rho \omega \dot{\omega}[\varepsilon v \circ \varsigma \delta \iota] \alpha \theta \dot{\varepsilon} \sigma \iota$. There is no mention of his father or his ancestors. Salutaris was an honorary Ephesian citizen, not an Ephesian by birth. ${ }^{24}$

Most likely, Salutaris' family had not been active in this city. Had they been prominent citizens of Ephesos, this would, indeed, have been the place to mention them in the honorary decree, before offering praise of Salutaris' own accomplishments. This, too, would have been the place to mention civic offices of Salutaris himself, had he held any. What is here mentioned instead are Roman military and procuratorial offices.

His cursus honorum is known from inscriptions to which I will return. He

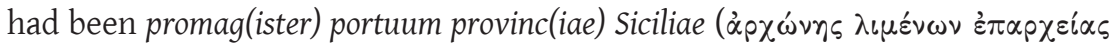

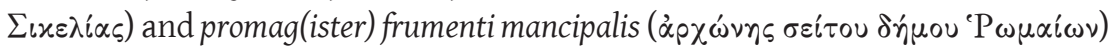
"manager of the custom dues of the province of Sicily", and "manager of the tax grain", also in Sicily. ${ }^{25}$ He then served as praefectus cohortis (है $\pi \alpha \rho \chi \circ \varsigma$ $\sigma \pi \varepsilon i \rho \eta \varsigma$ )

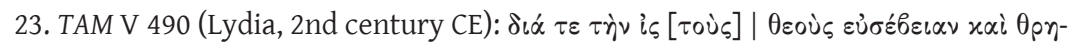

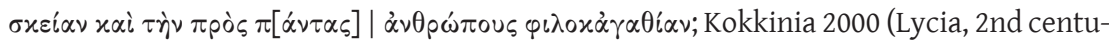

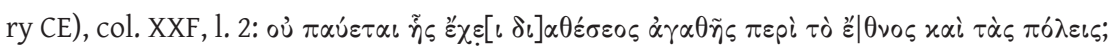

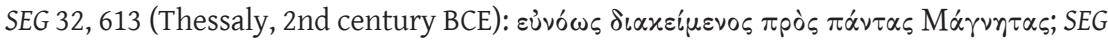

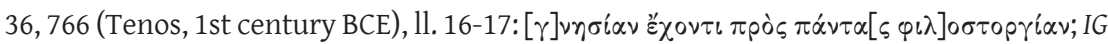

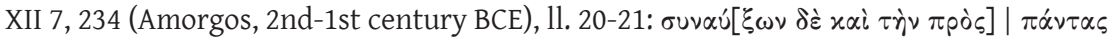

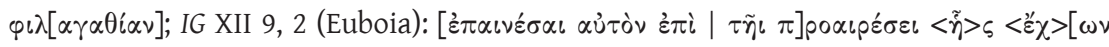

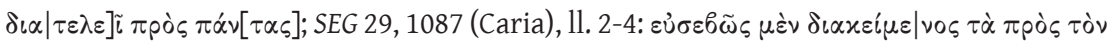

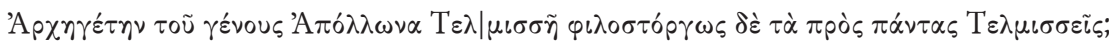

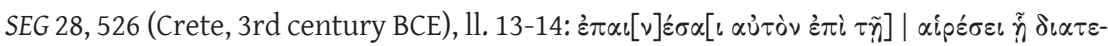

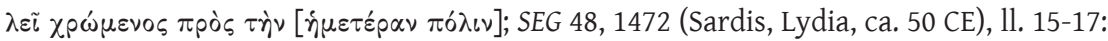

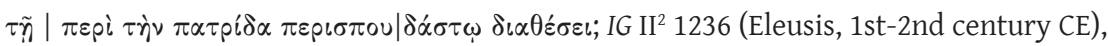

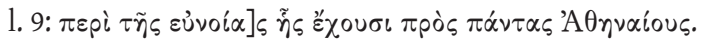

24. On Italians at Ephesos, see Kirbihler 2007 and Kirbihler 2016.

25. I am using R. Duncan-Jones' translation of these posts in Duncan-Jones 2016, 122. Boak 1915, 75 and 77-79, translates these as "Deputy Master of the port dues" and “Deputy Master of the corn rent”. On Salutaris' posts, cf. Devijver 1986, 134; Devijver 1977, V 106. Especially on the post of promagister frumenti mancipalis, see Nicolet 1991. 
and tribunus legionis ( $\chi \varepsilon i \lambda i \alpha \rho \chi \circ \varsigma \lambda \varepsilon \gamma(\omega \tilde{v} \circ \varsigma)$, but he did not serve as praefectus alae and therefore did not complete the tres militia. ${ }^{26} \mathrm{He}$ served instead as subprocu-

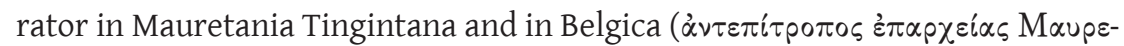

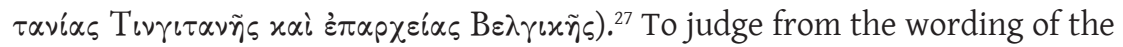
decree, at least two of these posts were held recently, under Trajan. ${ }^{28}$

Salutaris, then, had held only subordinate positions in the Roman administration. ${ }^{29} \mathrm{He}$ had no native status at Ephesos, and had limited experience in local politics. But he had cash, and the repeated processions of statues described above were only part of what he intended to do with it.

\section{Distributions and lotteries, and a "donation" of 20,000 denarii}

Salutaris also intended to provide money for distributions and lotteries. Once a year, as a rule either on the eve of or on Artemis' birthday, there would be: ${ }^{30}$

- A distribution among the members of the council of one denarius per member, for those who appeared in person at the temple to receive it (11. 222-229).

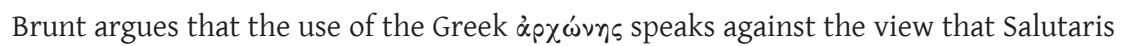
was acting in an official capacity, and that Salutaris was the local manager of publicani instead (Brunt 1990, 391, with n. 125).

26. Cf. Rogers 1991, 17.

27. A position below the procurator and probably above staff such as clerks, overseers, etc.; Eck 1997, 84.

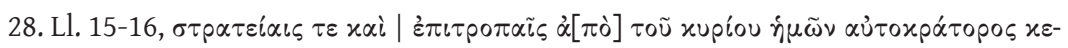

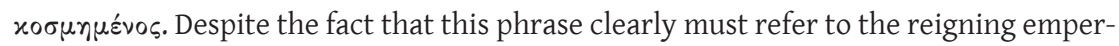
or, Rogers 1991, 17 with n. 53 (pp. 32-33) thinks the emperor must have been Domitian, because otherwise Salutaris would have held four posts between the years 98 (accession of Trajan) and 104 (the year of Salutaris' bequest). But the phrase need not refer to all four of Salutaris' posts, since they are not counted in that passage. If Salutaris held at least two posts under Trajan, then the phrase stands true for the reign of Trajan.

29. Boak 1915, 161, on the title magister: [the title] "was adopted for military, as well as civil, officials of the Empire. However, during the period of the Principate it was confined to various subaltern officers, none of whom ranked higher than a centurion."

30. A first, summary reference to Salutaris' donations for distributions (etc.) is partly preserved in 11. 62-73 of the honorary decree (document A). The subject of donations for distributions was possibly also included in the now missing lines 57-61. Ll. 62-73 have been restored on the basis of 11. 220-225. 
- A lottery among the members of the gerousia, in which winners would receive one denarius each (11. 231-238). ${ }^{31}$

- A lottery among the former provincial high priests (Asiarchs) (apparently of 11 denarii each, but the details are not secure; 11. 240-246).

- A lottery in which 2[50] members of each of the six tribes, that is 1.500 citizens, would receive nine asses each (11. 246-253).

- A lottery among the ephebes (the details are restored; 11. 253-258).

- A lottery among the theologoi (restored based on 1. 295; 11. 258-265).

- A distribution among the hymnodoi of Artemis (restored based on 1. 296; 11. 265-268).

- A donation to the temple officials who were responsible for carrying the statues (in this case not once a year but every time the statues were carried back and forth for a regular assembly; 11. 268-273).

- A lottery in which 49 winners among the children (paides) receive (a small sum that has been restored; 11. 273-279).

- A donation of 30 denarii to the person responsible for cleaning (either the statues or the sanctuary or both) each time the processions took place (1l. 280-284).

These yearly distributions, lotteries and donations were to be financed via a fund amounting to 20,000 denarii. ${ }^{32}$ As usual in similar cases, the donated sum was not meant to be spent, but was instead to be lent out on interest. The generated revenue would be divided among the several groups mentioned each year. In addition to the groups of recipients, the inscriptions list the amounts destined for each group, the officials who were to receive and administer the sums, and the purposes for which the money would be used.

It is not surprising to see the regulations stated in such detail. Other epigraphically attested foundations for religious festivities contain detailed regulations as well. One detail of Salutaris' donation of 20,000 denarii that does seem exceptional, however, is that the founder would keep the foundation capital himself, instead of handing it over to the city. He would hand it over to

31. According to Heberdey's restoration of lines 238-240, after the lottery of the gerousia there is mention of a distribution among the neokoroi in the house of Salutaris (on whose private Sebasteion, see pp. 233-235), but too much text is missing and it is doubtful that there is a sound basis for this restoration.

32. The sum survives in 1.305 and in 1.308 . 
the city when and if he wished. This important detail was noted by Hicks in the dossiers' first GIBM edition ${ }^{33}$ but was thereafter forgotten. ${ }^{34}$ The crucial passage was translated too favorably for Salutaris' posthumous fame once, and that translation has been repeated ever since. That passage, 11. 62- 72, reads:

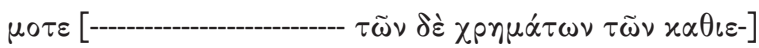

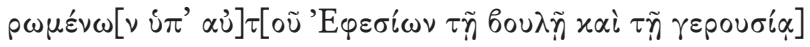

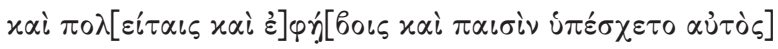

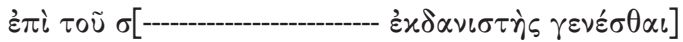

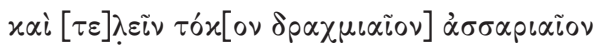

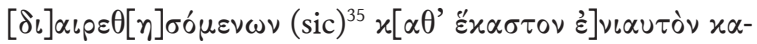

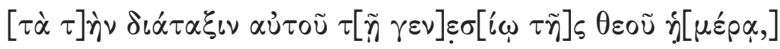

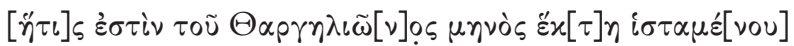

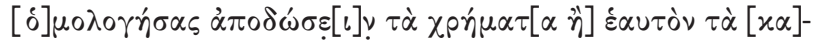

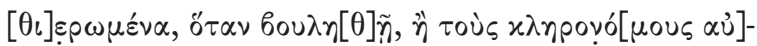

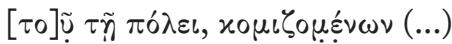$$
70
$$

Oliver translates 11. 70-71 as follows: "and he agreed that either he or his heirs would give the money to the city whenever it was wanted". ${ }^{36}$ The

33. Hicks 1890, 135; cf. ibid., 138. Hicks' edition was replaced by GIBM IV 481* (Marshall 1916), see also n. 4.

34. It has not helped that passages relevant to the terms of Salutaris' foundation are found in different places of this large dossier. These are: 11. 62-83, in the honorary decree, document A (1l. 64-74 on how the foundation money will be managed and dispensed; the rest concerns their ratification by the Roman authorities); 11. 126-129, at the end of the same decree, where measures are stated for protecting and preserving the foundation; 11. 220-315, in Salutaris' diataxis, document B (11. 222-284 on who will receive how much for what purpose, that is, distributions, lotteries, and payments; 11. 220-222 and 284-315 on how the foundation money will be managed, during Salutaris' life and after his death); 1l. 485-553, in Salutaris' additional diataxis, document G (ll. 488-549 on who will receive how much for what purpose; 11. 550-553 on 135 additional denarii donated for an immediate begin of the festival).

35. According to Heberdey $(1912,33)$ and IEph (1a, p. 174), the stone has $\Sigma$ OME$\mathrm{N} \Omega N$. Heberdey prints $[\delta \iota] \alpha \iota \rho \varepsilon \theta[\eta] \sigma o ́ \mu \varepsilon v[\mathrm{o}] \nu$ ("mason's error for $[\delta \iota] \alpha \iota \rho \varepsilon \theta[\eta] \sigma o ́ \mu \varepsilon v o \nu$ ”). IEph 1a prints $[\delta \iota] \alpha \iota p \varepsilon \theta[\eta] \sigma o ́ \mu \varepsilon v o v$ and places an asterisk below the omicron.

36. Oliver 1941, 70 . 
editors of Inschriften von Ephesos translate along the same lines: "er war damit einverstanden, daß (entweder) er oder (seine) Erben der Stadt das gestiftete Geld bei Bedarf auszahlen würden". ${ }^{37}$ Finally, Rogers: "he has agreed to give out the money dedicated, either himself, or his heirs, whenever it was wanted, to the city". ${ }^{38}$

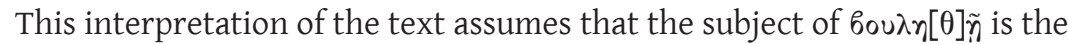
city: when the city needed the money, it would be handed over. But the city appears here in the dative $\tau \tilde{\eta} \pi \dot{\lambda} \lambda \varepsilon \iota$ and is clearly one of the two objects of

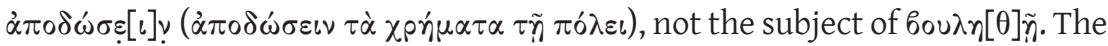
subject of $b_{0} \nu \lambda \eta[\theta] \tilde{n}$ is the same as the subject of the participle $[\delta] \mu 0 \lambda \circ \gamma \dot{\eta} \sigma \alpha \varsigma$ and the infinitive $\dot{\alpha} \pi \circ \delta \dot{\omega} \sigma \varepsilon[\iota] \mathrm{y}$, that is, Salutaris himself. ${ }^{39}$ Salutaris would hand over the money when he wished, and the same is said of his heirs.

He was also apparently free to earmark lands, to yield the 1,800 denarii each year, or not to, as lines 304-308 clearly suggest:

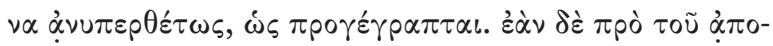

305

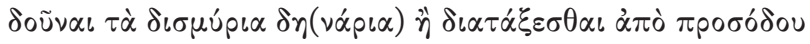

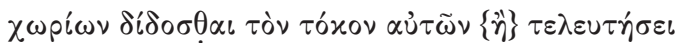

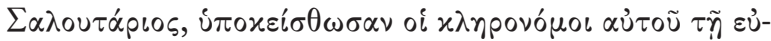

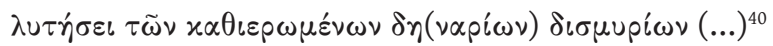

"And if he dies before handing over the 20,000 denarii, or before ordering that the interest be given from the revenue of lands, then his heirs will be liable to pay the consecrated 20,000 denarii."

\section{IEph 1a, p. 208}

38. Rogers 1991, 155.

39. ₹́uvóv, in the accusative instead of the nominative, although the subject of the infinitive is the same as that of the verb; the case of $\dot{\varepsilon} \alpha u \tau \grave{v} v$ has been assimilated to that

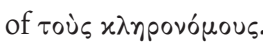

40. It is not clear that the $\ddot{\eta}$ before $\tau \varepsilon \lambda \varepsilon \cup \tau \dot{\eta} \sigma \varepsilon \iota$ in 1.306 is to be erased, as Hicks has done, followed by subsequent editors. The form $\delta \iota \alpha \tau \dot{\alpha} \xi \varepsilon \sigma \theta \alpha \iota$ may be mistaken instead: an infinitive instead of the conjunctive $\delta \iota \tau \tau \dot{\alpha} \xi \eta \tau \alpha$, which would make sense: "And if, before giving the 20,000 denarii, he either orders that the interest be given from the revenue of lands, or dies, then his heirs will be liable to pay the consecrated 20,000 denarii". There are a few other minor grammatical errors or deviations from classical grammar (cf. the é $\pi \iota \tau \varepsilon \lambda \varepsilon \tilde{\imath}$ for $\dot{\pi} \pi \iota \varepsilon \lambda \lambda \tilde{n}$, see n. 56), and a minor mason's error in the preceding line: lamda for alpha in $<\dot{\alpha}>\pi$ o $\mid \delta \circ \tilde{u} v \alpha \iota$. 
There is also mention of potential buyers of the lands that might be dedicated to financing Salutaris' processions and distributions. A buyer of such lands could either continue to pay the yearly interest of 1,800 denarii or give the capital to the city (and thus cease to pay that interest). A potential buyer, therefore, was no more obliged to hand over the 20,000 denarii than was Salutaris or his heirs. ${ }^{41}$ Salutaris would pay a fixed sum as yearly interest on his foundation capital, as if he had borrowed it from the city. But the foundation capital would not enter the city treasury at all, unless Salutaris or his heirs decided to part with it.

Two cases, from the same area and period, appear at first sight to be similar. Two decades later than Salutaris, in $124 \mathrm{CE}, \mathrm{C}$. Julius Demosthenes founded a quadrennial festival at Oinoanda in Lycia and promised to earmark, at an unspecified point in the future, landed property that would generate the sum of 4,450 denarii needed for his festival to take place. ${ }^{42}$ Until then, Demosthenes promised to donate 1,000 denarii each year, to be lent out at interest in order to generate that sum. From the words Demosthenes chooses in his promise to his city, it becomes obvious that the role of the ekdaneistes, that is, the lender on behalf of the city, entailed financial risk for the person who undertook it. Demosthenes, therefore, did his city an additional service by appointing a relative to act, for a certain period, as lender of the sums that Demosthenes donated. ${ }^{43}$

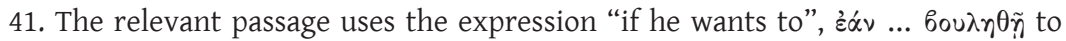
refer to the buyer's choice between handing over the capital or paying the interest (l. 285 and 1.289):

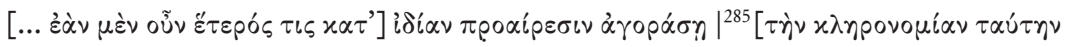

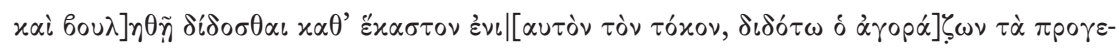

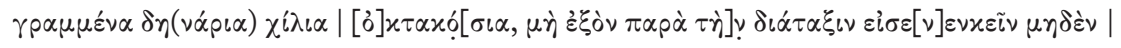

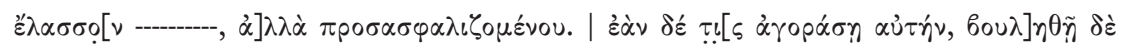
$\dot{\alpha} \pi \circ \delta \circ \tilde{\nu} \nu \alpha \iota \tau \dot{\alpha} \chi \varepsilon\left\llcorner\iota \nu \tau \dot{\alpha} .\left.\tau \tilde{\eta} \varsigma\right|^{290} \varkappa \alpha \theta \iota \varepsilon \rho \dot{\omega}[\sigma \varepsilon \omega \varsigma \dot{\alpha} \rho \chi \alpha \tilde{\alpha} \alpha \ddot{\alpha} \pi \alpha \nu \tau] \alpha\right.$.

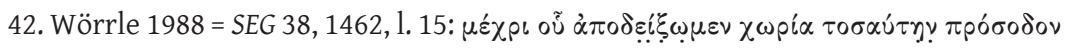
$\sigma \dot{\omega} \zeta \varepsilon \iota \nu \delta u v \alpha ́ \mu \varepsilon v \alpha$.

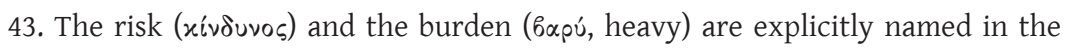

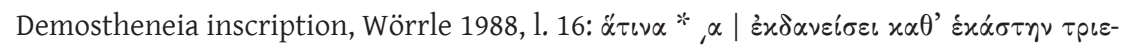

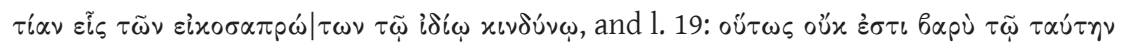

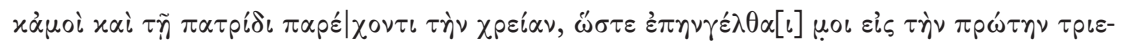

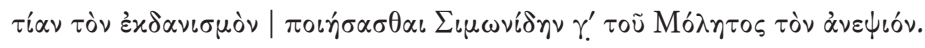


In another epigraphically attested case, also from the 2 nd century $\mathrm{CE},{ }^{44}$ Lalla of Tlos promised her city 12,500 denarii and offered to pay the interest on this sum herself each year, so that the city need not elect lenders and debt collectors, as a decree in her honor states. ${ }^{45}$ Demosthenes of Oinoanda and Lalla of Tlos, then, gave a certain sum to the city, and in addition helped the city to generate profit from the donated capital, in other words they relieved their city of the task of lending the donated capital to yield revenue.

Salutaris, by contrast, kept the 20,000 denarii, promising to act as lender and to return to the city 1,800 denarii per annum, which amounts to nine percent interest. Salutaris refers to this rate in both diataxeis (documents B and

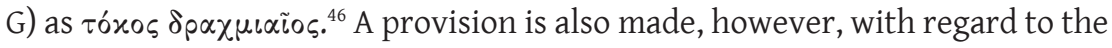
interest rate, in case the capital was given to the city at some point: in such case, as we learn from 1.302 of document B, the various constituencies among which the sum of 20,000 was to be divided were to lend out the money at a

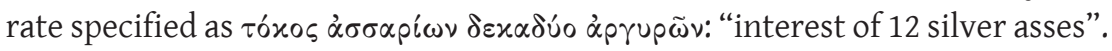

44. Dated on paleographic evidence to the middle of the 2nd century CE: Naour 1977, 266.

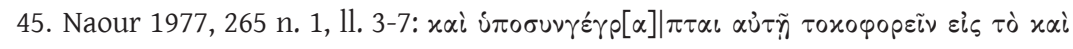

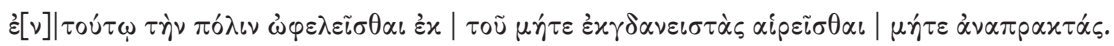

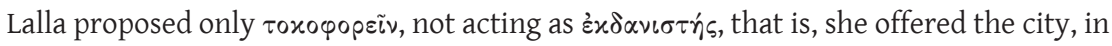
addition to the capital, the amount of money that the capital would bring if it were lent.

46. In 1.66 of the honorary decree, document A, the interest rate has been restored

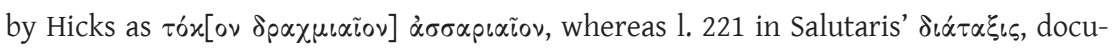

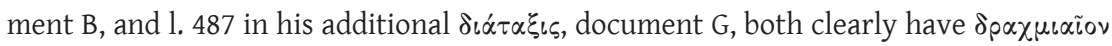

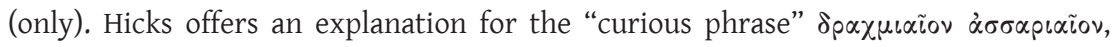
based on the (proposed) difference between nominal value and exchange value of the as at Ephesos (1/16 as opposed to 1/18 of the denarius): Hicks 1890, 139; see also Melville Jones 1971, 100-101. But the supplement [ $\delta \rho \alpha \chi \mu\llcorner$ io $]$ is not secure. To judge by Heberd-

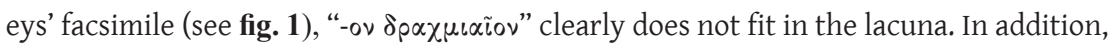
the expression $\delta \rho \alpha \chi \mu\llcorner\alpha$ iov $\alpha \sigma \sigma \alpha \rho\llcorner\alpha i o v$ would be a hapax. The missing letters after the "-ov" of $\tau o ́ x[o v]$ must therefore have belonged instead to a numeral, as in the testament

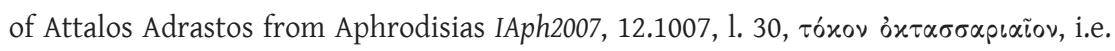
interest rate of eight asses (2nd century CE). In 1.66 of the Salutaris dossier we should restore $\tau \hat{o} x[0 \nu$-(4-6)-] $\alpha \sigma \sigma \alpha p \prec \alpha i ̃ o v$. The missing numeral must have expressed the interest rate of one drachma in asses. Cf. IKibyra 42, 11. 12-13, where we are told explicitly how many asses the Rhodian drachma was worth at Kibyra in the 1st century CE. 
Scholars have tried to make sense of this number, and particularly to reconcile it with the rate of nine percent. ${ }^{47}$ But it should be noted that $\tau$ óxos

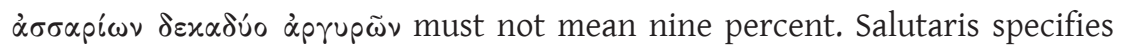
which sum he was going to give to the city, that is 1,800 a year, and he expresses this also in terms of a rate of interest on the 20,000 denarii, that is róxos $\delta p \alpha \chi \mu<\alpha i o s$. The rate of interest at which he requires the 20,000 denarii to be lent in case the capital migrates from his treasury to that of the city, however,

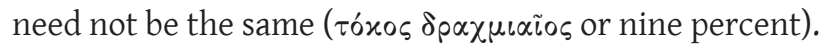

There is no evidence, in fact, that Salutaris placed himself under an obligation to lend the 20,000 denarii at the same rate as that at which the city was to lend the money in order to ensure the financing of Salutaris' festival -should the city ever receive the capital. There is no evidence, for that matter, that Salutaris put himself under an obligation to lend the 20,000 denarii at the rate at which he "borrowed" it from the city. Salutaris' intention, or "plan A", was that the capital stayed in his treasury, where it would be available to him to be lent at whatever rate he himself wished. According to what we could call his "plan B", at some unspecified point in time Salutaris or his heirs would reserve estates for the purpose of financing the festival. That the city received the capital was only a third possibility. The rate $\dot{\alpha} \sigma \sigma \alpha \rho i \omega \nu ~ \delta \varepsilon x \alpha \delta \dot{o} \circ \dot{\alpha} \rho \gamma u \rho \tilde{\omega} \nu$ is relevant to this, last, scenario, and it is not inevitable that the same rate was intended here as in Salutaris' "plan A".

Assuming that a different rate of interest was intended in case the money ended up being administered by the city officials, as opposed to the city receiving a fixed sum from Salutaris each year, may help explain how the word $x$ ó $\lambda$ $\lambda \cup b o s$ was used in the Salutaris dossier. The word is attested in a fragmentary passage of document B, 11. 251-252. That passage has been restored, plausibly, to mean that a larger xó $\lambda \lambda$ ubos might allow for a larger number of winners in the lottery among the members of the tribes. Lines 229-230 and 236-237 apparently also mentioned the xó $\lambda \lambda u b \circ s$, in connection with a distribution to the members of the council and a lottery among the members of the gerousia. ${ }^{48}$

47. Hicks 1890, 139; Melville Jones 1971.

48. The two passages have been restored based on 11. 251-252. In both cases, the word xó $\lambda \lambda$ ubos itself does not survive but there are close similarities to 1l. 251-252, especially 1.236 with the phrase $\omega \sigma \tau \varepsilon \varepsilon$ sis $\pi \lambda \varepsilon_{i} i_{0}[\nu \alpha \varsigma]$. Certain details of the restorations in question, however, should be regarded as exempli gratia, as for example $\mu \varepsilon i \zeta \omega \nu \gamma \varepsilon i v \eta \tau \alpha \iota$, supplied in 1.229, or $\mu \varepsilon i \zeta \omega \nu \tilde{n}$, in 1. 251. 
Kó $\lambda \lambda u b o s$ is a word with a long history and more than one meanings. ${ }^{49}$ In the passage in question, it has been translated as "the rate of exchange", as in LSJ xó $\lambda \lambda$ ubov II. But this makes little sense in the case of Salutaris' donation, where the various prizes and gifts were financed through the lending out of the donated capital on interest. If we suppose that the need to exchange denarii for asses affected the sum available in the lottery among the members of the tribes, where asses were paid out, we should not expect the kollybos to be mentioned in connection with the distribution among the members of the council and with the lottery among the members of the gerousia, where the gift (in the distribution) and price (in the lottery) would be one denarius. ${ }^{50} \mathrm{We}$ may consider the possibility, therefore, that, in the Salutaris dossier, xó $\lambda \lambda u b \circ 5$ had a sense closely related but not identical to LSJ xó $\lambda \lambda$ ubov II: the profit obtained through a financial transaction. In this case xó $\lambda \lambda_{u} b{ }_{0}$, , here, should be understood as meaning not the rate itself but the revenue generated when a rate is charged in a financial transaction. ${ }^{51}$ If this interpretation is correct, $x$ ó $\lambda$ $\lambda \cup b o s$ in the Salutaris dossier referred to the sum gained when the money was lent out, and was used, in this particular case, synonymously with róxos. When and if the 20,000 denarii left Salutaris' treasury and ended up administered by the city, that sum would be lent at a different rate than the nine percent on Salutaris' figurative loan of his own money, it would generate a different revenue than the 1,800 denarii, and therefore there would be a different sum available for the lottery. ${ }^{52}$

49. See most recently five studies published by Burkhalter 2014.

50. The passages 11. 229-230 and 236-237, mentioned above, refer to a distribution of one denarius to the members of the council, and to prizes of one denarius each in a lottery among the members of the gerousia.

51. Cf. Bresson 2014, 531-532, interpreting xó $\lambda \lambda u b o s$ as the "produit de l'application du taux de change" (citation from p. 531).

52. Understanding xó $\lambda \lambda \cup b_{\circ} \varsigma$ as the profit obtained through a financial transaction would be helpful also in the case of syll. ${ }^{3}$ 672. In that inscription, from Delphi of the middle of the 2nd century BCE, 1l. 31-32, it is said that money from the xóndubos could be

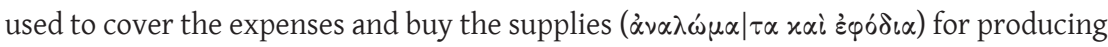
two copies, on whitened boards, listing the names of borrowers, the sums, the securities, etc., of a royal fund for the benefit of the education of the children: $\tau \dot{\alpha} \delta \dot{\varepsilon} \dot{\alpha} \nu \alpha \lambda \omega \mu \alpha \mid \tau \alpha$

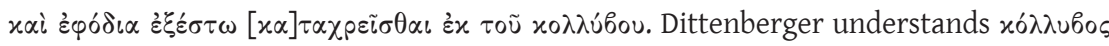


To sum up, the 20,000 denarii were "consecrated" or "dedicated" ( $\varkappa \alpha \theta \varepsilon \rho \omega$ $\mu \varepsilon ́ v \alpha$, a word used remarkably often in this text), but they stayed with Salutaris. Salutaris names no point in time when he must hand the capital over. He or his heirs were free to hand the money over when they wished. ${ }^{53}$ Although, as mentioned above, this is to my knowledge unprecedented in similar foundations, the same thinking can be found in the other half of Salutaris' foundation, described earlier, that is, his donation of statues.

\section{Salutaris' imperial couple}

The two statues, of Trajan and of his wife Plotina, were to be, again, "dedicated", but kept in Salutaris' possession until he died. It is stated clearly that the statues would be given to the grammateus of Ephesos by Salutaris' heirs after his death, "so that these too be placed above the seats of the council during the assemblies, [together with] the golden Artemis and the other images" (1l. 154-158):

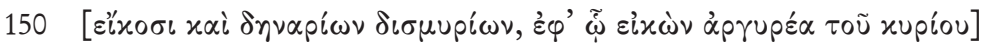

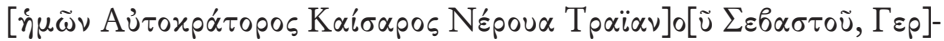

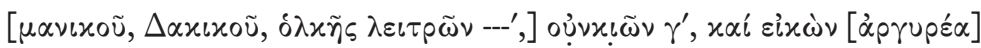

to mean the rate of exchange of the Alexandrian drachmai that Attalos II had donated into drachmai of the Aeginetan standard used at Delphi (Syll. ${ }^{3}$ II, p. 250 n. 12). However, the costs for producing and displaying the lists of borrowers would be recurrent, not a one-off expense at the time when the donated capital was exchanged. Bresson's interpretation is therefore more convincing according to which xó $\lambda \lambda u b o s$ in the Delphic inscription was a civic tax on the exchange of money (Bresson 2014, 527; cf. Rousset 2004, 112). Possibly, however, xó $\lambda \lambda u b$ os meant the revenue obtained from lending out the donated capital. The use of $\varepsilon \varphi \rho ́ \delta \iota \alpha$ has perplexed Bresson, who wonders whether embassies to Attalos were intended, though none are mentioned in the inscription (loc.cit.). But $\varepsilon \dot{\varphi} \delta_{\delta} \iota \alpha$ can also mean resources or supplies, generally, without reference to travel.

53. His heirs are not named and for all we know he may have had none at the time of the foundation. However, there is no evidence to suggest that he made his foundation because he had no heirs, as Schulte assumes, nor that his foundation consisted of "a great part of his fortune" ("einen großen Teil seines Vermögens"; Schulte 1994, 518). On the size of Salutaris' foundation, see below, p. 244. It is also unlikely that the foundation was made when Salutaris was very old (Schulte, loc.cit.: "bei seinem Tode") because he had held administrative posts recently, under Trajan; see n. 28. 


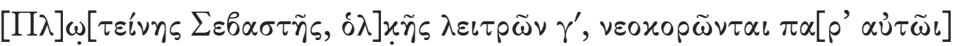

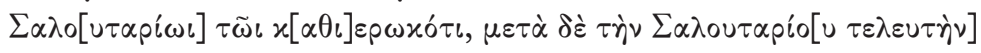

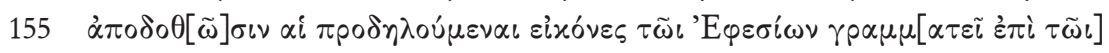

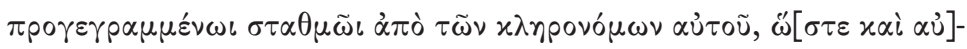

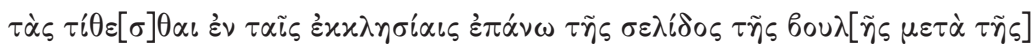

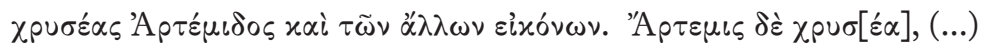

"[... on the condition that a silver image of our lord Imperator Caesar Nerva Traianus Augustus Germanicus, Dacicus, weighing ... pounds and] three ounces, and a [silver] image (152) of Plotina [Augusta] weighing three pounds, be housed and tended to by the dedicator Salutaris [himself], and after Salutaris' [death] the aforementioned images be given (155) by his heirs to the Secretary of the Ephesians, [at the] weight written above, so as these too be placed above the seats of the council (157) during the assemblies, [together with] the golden Artemis and the other images."

Heberdey assumed that the two statues were to receive special worship at Salutaris' home and commented no further. The editors of IEph translated the passage unambiguously, but they too, like Heberdey, paid no more attention to it. ${ }^{54}$ The Austrian archaeologists and epigraphists working at Ephesos in recent years, however, while investigating a structure that they presumed to be Salutaris' house (see below, p. 243), expected to find a private Sebasteion there, on the basis of the passage translated above..$^{55}$ Their interpretation of that passage is that Salutaris was donating statues that would be placed at his home during his lifetime.

It may be worth noting, however, that the verb used in the relevant pas-

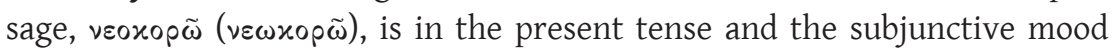

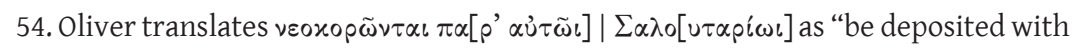
Salutaris himself", which renders correctly the fact that the statues were to be kept at Salutaris' home (Oliver 1941, 71). This is not clear in Rogers' translation "to be cared for by Salutaris himself", and Rogers' discussion of the dossier includes no mention of this. For Rogers' translation to be correct, the Greek should have been i $\pi$ ' $\alpha \dot{u} \tau 0 \tilde{u}$, not $\pi \alpha \rho$ ' $\alpha \dot{\tau} \tau \tilde{\omega} \iota$. But the first half of the preposition $\pi \alpha \rho \dot{\alpha}$ survives. If the stone had $\pi \alpha \rho$ ' $\alpha \dot{\tau} \tau \circ \tilde{u}$ then we might consider Rogers' interpretation, but Heberdey was right to supply the much more common $\pi \alpha\left[\rho^{\prime} \alpha \dot{\tau} \tau \tilde{\omega} \iota\right]$.

55. Taeuber 2005; cf. Taeuber 2010, 472. 


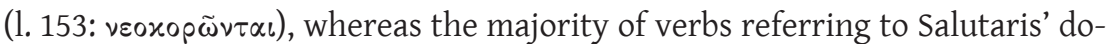
nations are in the future tense and/or the imperative mood. ${ }^{56}$ This is an indication that, in contrast to the rest of the sculptures that Salutaris donated, the statues of the imperial couple were already in Salutaris' possession and probably at his private Sebasteion when that text was written. This brings to mind Pliny the Jounger's donation to the Umbrian community of Tifernum Tiberinum of imperial statues that he already owned. ${ }^{57}$

This detail is interesting considering that Salutaris' additional donation (document G, 11. 447-568) consists of two statues, Athena and Concordia (plus silver for silver-coating their statue-bases, and 1,500 denarii). I doubt that it is by coincidence that the number of statues added equals the number of statues which would remain at Salutaris' home according to his initial foundation. I want to suggest instead that Salutaris made an additional donation because his foundation as originally envisaged was not accepted unanimously and in every detail.

\section{Honors and gifts, friends and foes}

Bargaining was a part of the euergetic process. Sometimes a euergetes proposed a gift to the city, and the city asked for something more, and/or for something else. In the case of Vibius Salutaris, there is direct evidence that the recipients of his generosity immediately proposed changes to his foundation. The dossier includes two decrees of the council of Ephesos, documents $\mathrm{E}$ and $\mathrm{F}$,

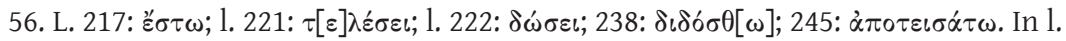
223 we have ö $\pi \omega \varsigma$ ह่ $\pi \iota \tau \varepsilon \lambda \varepsilon \tilde{\iota}$ (indicative!), which is probably mistaken for ö $\pi \omega \varsigma \varepsilon ่ \pi \iota \tau \varepsilon \lambda \tilde{\eta}$, written correctly in the subjunctive mood in 1. 254 ([ö $\pi \omega] \varsigma$ हे $\pi \iota \tau \varepsilon \lambda \tilde{n}) ; 11.275-276$ : [ö $\pi \omega \varsigma]$

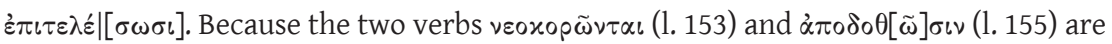
in the subjunctive mood, Hicks, followed by subsequent editors, rightly assumed that the almost completely lost preceding lines (11. 141-152) must have contained a condi-

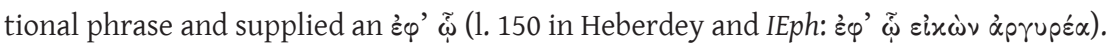
Salutaris gave the statues "on the condition that". Since the future passive does not have a form for the subjunctive mood, the subjunctive mood of the aorist passive is used to express the subjunctive mood in the future tense, as in 1.155: $\alpha \pi \circ \delta \circ \theta[\widetilde{\omega}] \sigma \iota v$. Had the drafter of Salutaris' diataxis wished to use the future tense in 1.153, the form would

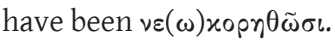

57. Plin. Ep. 10.8. 
that date from the same year as the other documents and that modify certain regulations of Salutaris' original diataxis (document A) concerning who would carry the statues and where those who carried them would sit in the theatre. ${ }^{58}$

The city might ask a benefactor for more or for different gifts, knowing that to accept a gift was to promise some sort of reciprocation. With his gifts, a euergetes might buy a vague promise for preferential treatment by the city authorities in connection with his economic activities, but there are only hints in this direction..$^{59}$ What is clearly documented as a reciprocal gift to the euergetes is the privilege of honorary commemoration. As far as the inscriptions are concerned, euergetai sought "affective rewards". ${ }^{60}$ Such rewards could be carved in stone. Inscriptions beyond the texts displayed at the theatre's entrance played a major role in perpetuating Salutaris' name. The bases for the statues of Salutaris' processions, and the statues themselves, are worth a closer look.

The inscriptions of the dossier give the weight of each statue. This ranges between three and seven Roman pounds, that is, a little over half a kilo to 2.5 kilos. Heberdey, therefore, followed (although not consistently) by the authors of IEph, spoke of "Statuetten", statuettes or figurines. This information was lost in most subsequent epigraphic and historical discussions. ${ }^{61}$

It is true that we cannot infer with certainty the size of silver sculptures from indications of weight alone since we do not know enough about their construction..$^{62}$ This may explain, at least partly, why scholars have had nothing

58. Documents E and F, 11. 414-430 and 431-446.

59. Dio Chrysostomos' removing of older structures to build new shops in his native Prousa in Bithynia became the subject of criticism among his fellow citizens (Or. 46.9) and may hint at ways in which important citizens might turn influence into profit. Cf. Kokkinia 2009, 200-201, for Licinius Priscus Juventianus and his shops at Corinth. Dio was also accused of exploiting his assignment to supervise the construction of a public building to secure a prominent spot for a family grave (Plin. Ep. 10.81-82).

60. MacMullen 2014, 2, who does not, however, seem to take into account that our sources, inscriptions in particular, were unlikely to divulge the relevant information, were a euergetes to seek material rewards.

61. A book published in 2015 even speaks of "large statues": Graf 2015, 42. See, however, n. 63.

62. On Roman silver and gold statues, see Lahusen 1999. On the weight of bronze statues and statuettes, see Biard 2017, 226 with n. 10. 
to say about the small size of Salutaris' statuettes. ${ }^{63}$ However, several of those stone bases, seven to be precise, or at least fragments thereof, survived (IEph 1a 28-35). They were of white marble, rectangular -and small: only $64 \mathrm{~cm}$ long and $37 \mathrm{~cm}$ deep. Considering that three sculptures would be placed on each base, those statues must have been very small indeed.

The triads, then, consisted of statuettes. But the bases, though they would have been too small for three large sculptures, were large enough to carry ca. 22 lines of a bilingual dedication, consisting, mainly, of Salutaris' cursus honorum in Latin and in Greek.

\section{[Dianae Ephesiae]}

[et Ephesiorum gerusiae]

[C(aius) V]ibius, C(aii) f(ilius), Vof(entina), Salutaris, promag(ister) portuum provinc(iae) Sicilia[e,] item promag(ister) frumenti mancipalis, praefec(tus)

5 cohor(tis) Astur[u]m et Callaecorum, trib(unus) mil(itum) leg(ionis) XX[II] Primigeniae $\mathrm{P}$ (iae) F(idelis), subpro-

curator provinc(iae) Mauretaniae Tingitanae, item provinc(iae) Belgicae

Dianam argenteam, item imagines argenteas duas, unam urbis Ro-

manae et aliam gerusiae, sua pecunia fecit ita, ut omni ecclesia su[p]ra

bases ponerentur ob quarum dedicationem in sortition $[\mathrm{em}]$ gerusiae con-

10 secravit sestertia decem septem millia nummum.

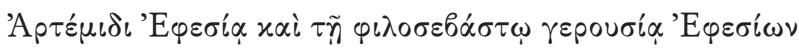

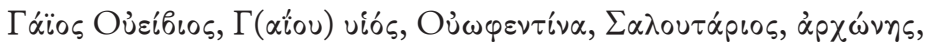

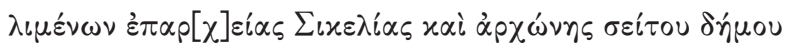

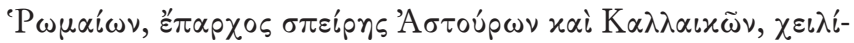

63. Rogers 1991 always speaks of statues. By contrast, an article by D. Ng (Ng 2018), which appeared after this paper's first submission to Tekmeria, consistently refers to statuettes. Images carried in procession could be anything from hand-held to large. On processional statuettes, see Madigan 2013. Though otherwise useful, Lahusen 1999 is inconclusive in this respect. When the Athenians informed the emperors Marcus Aurelius and Commodus of their intention to construct images (sixóves) of them and their wives (apparently of gold), the emperors, demonstrating their modesty, advised them to make busts ( $\pi \rho \circ \tau \circ \mu \alpha \dot{s})$ ) of bronze instead, of moderate size, which could more easily be carried to the assemblies: Oliver 1941, no. 24, 1l. 33-37 (pp. 111-112). Concerning the precious metals, the emperors' answer followed Trajan's exemplum: Plin. Pan. 52.3, "Itaque tuam statuam ... aeream cernimus". 


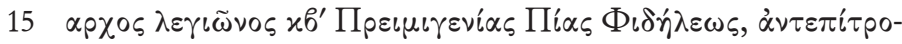

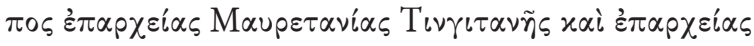

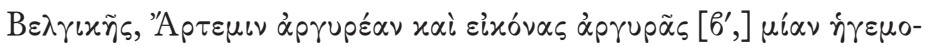

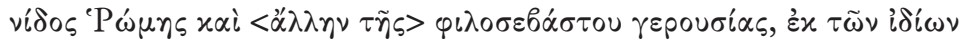

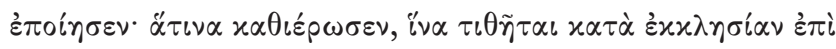

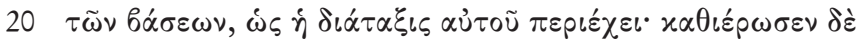

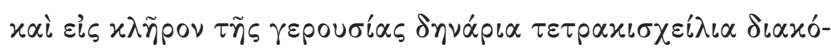
$\sigma \iota \alpha \pi \varepsilon v \tau \eta \dot{x} x о \nu \tau \alpha$.

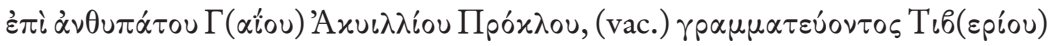

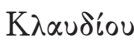

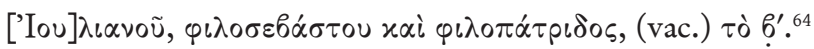

"To Artemis Ephesia and to the emperor-loving gerousia of the Ephesians, Gaius Vibius Salutaris son of Gaius of the tribe Oufentina, < who has served as> chief contractor for the port dues in the province of Sicily, chief contractor for the public grain <of the province of Sicily>, prefect of the cohort of the Asturians and Gallaecians, tribune of the Legio XXII Primigenia Pia Fidelis, subprocurator of the province of Mauretania Tingitana, subprocurator of the province of Belgica, has caused to be made at his own expense a silver Artemis and also two silver images, namely, one of the ruling city Rome and another of the emperor-loving gerousia, which he presented as a dedication in order that they might be placed at each assembly upon their bases, as is contained in the deed of gift. He also gave 4,250 denarii as an endowment for a distribution by lot to the gerousia. In the proconsulship of Gaius Aquillius Proculus. In the second secretaryship of Tiberius Claudius Julianus, emperor-loving and patriotic." 65

Whereas the statuettes would be carried back and forth from the Artemision to the theatre in frequent processions, the bases, once set up at the theatre, remained there. Vibius Salutaris' name and career in the Roman administration became a fixture at Ephesos' theatre. More precisely: a part of the balustrade, because the bases were installed between balustrade slabs. ${ }^{66}$

And that name and career were repeated not only nine times, as one would expect according to the regulations of Salutaris' foundation, but 29 times.

64. IEph 1a 35.

65. Transl. Oliver 1941, no. 4, pp. 86-87.

66. IEph 1a 28, p. 223. 
Next to the seven bases mentioned, which carry the dedications known from Salutaris' foundation, another four bases of white marble (or fragments thereof) have been found, in the same style as the others. ${ }^{67}$

These four bases, too, were inscribed, and they commemorated the dedicant with his full cursus honorum, in this case only in Greek. But these bases belong to a different dedication. We learn from their inscriptions that Salutaris had dedicated statues of "all the gods that are called upon during the assemblies". ${ }^{68}$ We do not know which and how many those gods were, but we do learn from the inscriptions on the four surviving bases how many bases were originally constructed for them: the statues of the gods stood on 20 bases. ${ }^{69}$

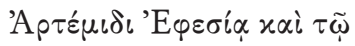

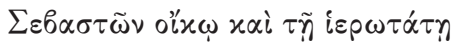

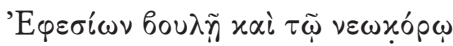

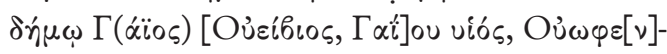

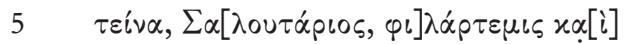

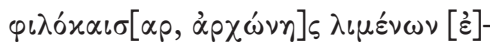

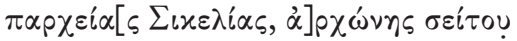

$$
\begin{aligned}
& \delta \dot{\eta} \mu \sigma \mathrm{U}^{~} \mathrm{P} \omega[\mu \alpha i \omega \nu, \text { है } \pi \alpha \rho] \chi \circ \varsigma \sigma \pi \varepsilon i p \eta s \\
& \text { 'A } \sigma \tau 0 u ́ \rho \omega \nu[x \alpha i \mathrm{~K} \alpha \lambda \lambda \alpha \omega x \tilde{\omega}] v, \chi \varepsilon \iota \lambda i \alpha \rho \chi 0[s]
\end{aligned}
$$

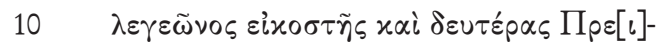

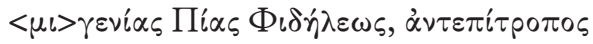

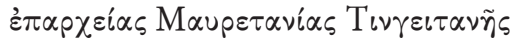

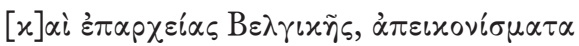

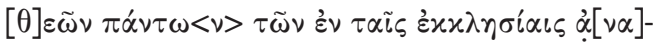

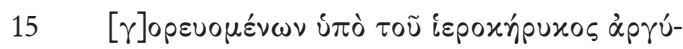

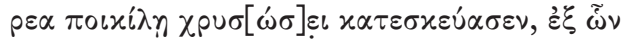

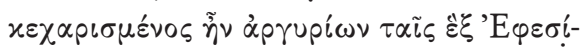

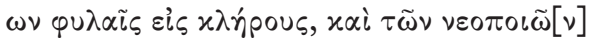

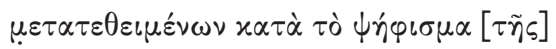

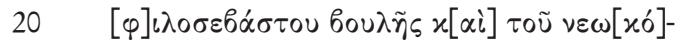

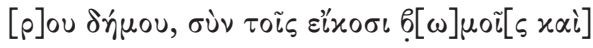

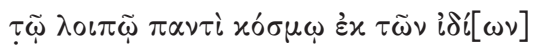

67. IEph 1a 36 A-D.

68. IEph 1a 36 A-D 1. 13-14.

69. IEph 1a 36 A-D 1. 21. 


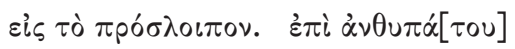

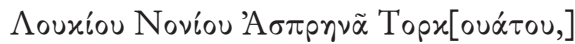

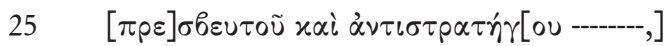

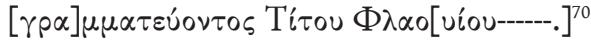

"To Artemis Ephesia and to the imperial house, and to the most sacred council of the Ephesians, and to the people, warden of the (imperial) temple, Gaius Vibius Salutaris, son of Gaius of the tribe Oufentina, (5) Artemis-loving and emperor-loving, [manager] of the custom dues of the province [of Sicily], manager of the tax grain for the (8) Roman people, prefect of the cohort of the Asturians and Callaecians, tribune of the Legio XXII Primigenia (11) Pia Fidelis, subprocurator of the province of Mauretania Tingitana and (13) of the province of Belgica, has constructed images (14) of all the gods whom the sacred herald calls upon in the assemblies, silver with colorful (or varied) gilding, from the money (17) which he had donated to the tribes of the Ephesians for lotteries, and on account of the board of the neopoioi (19) having re-alocated ${ }^{71}$ (the money) in accordance with the decree of the emperor-loving council and of the people, warden of the (imperial) temple, (21) including the 20 bases and all of the other adornments, at his own expense for the rest (of the sum needed). ${ }^{72}$ In the proconsulship of Lucius Nonius Asprena Torquatus, when [---] was proconsular legate, in the secretaryship of Titus Flavius [---]."

70. IEph 1a $36 \mathrm{~A}$.

71. The editors of IEph translate $\mu \varepsilon \tau \alpha \tau \varepsilon \theta \varepsilon \iota \mu \varepsilon ́ v \omega \nu$ "der anderen Verwendung zugestimmt haben", "they have agreed with the different use" (IEph 1a, p. 243). Although it is of no great significance for understanding this passage -the neopoioi did obviously agree with the change of use decreed- the middle $\mu \varepsilon \tau \alpha \tau i \theta \varepsilon \mu \alpha \iota$ (of $\mu \varepsilon \tau \alpha \tau i \theta \eta \mu_{\iota}$ ) must have here the same meaning as in 1.403 of the letter of Afranius Flavianus: $\dot{v} \pi \grave{o} \mu \eta \delta \varepsilon v o ̀ s$

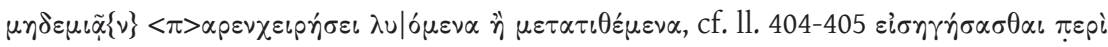
$\tau \tilde{\eta} \varsigma \mu \varepsilon \tau \alpha \theta \dot{\varepsilon}<\sigma \varepsilon>\mid \omega \varsigma$ $x \alpha i \mu \varepsilon \tau \alpha \delta\llcorner о\llcorner x \dot{\eta} \sigma \varepsilon \omega \varsigma$, as also, to name only one out of the multiple examples beyond the inscriptions of Ephesos, in Didyma (I.Didyma 488, 11. 43-44): $\omega s$

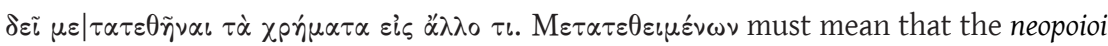
re-allocated the sums. They did so in accordance with the decree of the council and the people, $x \alpha \tau \dot{\alpha} \tau \grave{~} \psi \dot{\eta} \varphi \iota \sigma \mu \alpha$.

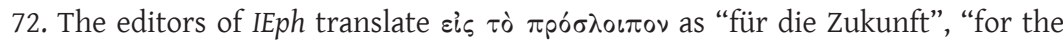

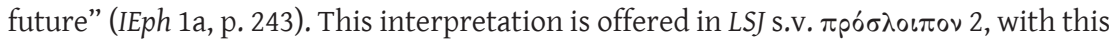
occurrence providing the sole example. It is, however, unlikely, that this is what was

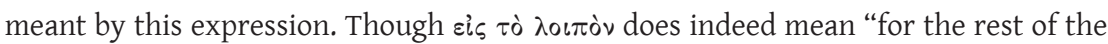


The inscriptions on those bases tell us two more things: first, that the money for those 20 or more statues of the gods had come from a re-allocation, per decree of the council and the demos, of the funds that Salutaris had destined for lotteries among the members of the tribes. ${ }^{73}$ Second, that the statues were set up during the proconsulate of L. Nonius (Calpurnius) Asprenas Torquatus, known from other sources, and dating from or near the year $107 \mathrm{CE}{ }^{74}$ In other words, a few years after Salutaris' foundation, there had been yet another change in Salutaris' original plans (beyond the changes recorded in documents $\mathrm{E}$ and $\mathrm{F}$ ), one that resulted in a threefold increase of monuments with Salutaris' name inscribed on them in Ephesos' theatre. Instead of 1,500 Ephesian citizens receiving nine asses each in a lottery each year (see p. 226), the sum originally dedicated for that purpose was used to make statues of the gods placed on 20 bases inscribed with Salutaris' cursus honorum.

One wonders whether Salutaris' inscribed name was as ubiquitous in the rest of Ephesos as it was in the city's theatre. According to the honorary decree included in the dossier (document A, 11. 85-88), Salutaris was awarded statues as thanks for his foundation, at the Artemision and elsewhere. A base for an honorific statue of him has, indeed, been found in the theatre (IEph 1a 37). Other than that, however, Salutaris is mentioned only in two inscriptions at Ephesos, both of which he erected himself. He set up a statue for the first Roman

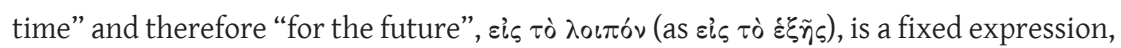
used frequently both in literary and in epigraphic texts, and there is no sound basis

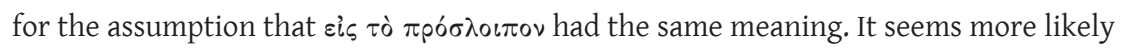
that $\pi \rho \circ \sigma \lambda \circ$ o $\pi \circ v$, which is attested only in papyri and inscriptions, is in fact the word $\pi \rho \circ \sigma \lambda \varepsilon i \pi{ }^{2}$, attested already in Arist. Pol. 1337a. It means "this which is lacking", and this meaning suits our text much better. The expense for the 20 statues and their bases, and the "rest of the decorations" proved higher than the sum that had been dedicated to lotteries for the tribes, and Salutaris provided that sum too, referred to as $\tau \grave{o} \pi \rho \circ-$

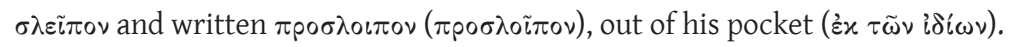

73. IEph 1a, p. 168, "Der für Zinszahlungen an die Gerusie bestimmte Anteil des Kapitals wurde bereits einige Jahre später für weitere Statuetten verwendet; vier Basen sind erhalten, vgl. Nr. 36 A-D" is wrong. It was not the money for the gerousia that was re-directed, but the money for a much larger body of citizens, that of the six tribes. Op.cit. p. 241 has the correct indication.

74. RE XVII (1936), 877-878, s.v. Nonius 31 (E. Groag); Eck 1982, 345; Thomasson 1984, 26 (Asia), no. 93 (col. 221). 
senator from Lycia, M. Arruntius Claudianus (who also began his career as an equestrian but went well beyond the tres militiae) (IEph 3 620). He also set up a statue for L. Nonius Asprenas Torquatus, the proconsul in whose term money was divested from Salutaris' lotteries to make 20 more statues. ${ }^{75}$ Salutaris calls Claudianus his friend and benefactor, and Torquatus his friend. ${ }^{76}$

And, apparently, he had more friends in the Roman provincial administration. Two letters included in the dossier, one by the proconsul Aquilius Proculus and another by his legate Afranius Flavianus, both address the city of Ephesos and both praise Salutaris, as expected. The epistles are not well preserved, but in those passages that are secure, both the proconsul and his legate refer to Salutaris as a friend among their closest. Flavianus even says something along the lines that he knew better than "most people" what an important euergetes Salutaris was. ${ }^{77}$ One should not read too much into the rhetoric of friendship in honorific monuments and letters of recommendation, but we can safely infer from these words and from the monuments for Claudianus and Torquatus that those four functionaries of the Roman state were, at least, no strangers to Salutaris.

If he was not of local origin, which, as I mentioned above, he almost certainly was not, local worthies (more likely than hoi polloi or "most people", as Flavianus writes) could have reacted negatively to Salutaris' sudden fame. Salutaris may indeed have had more friends in the provincial administration than among the members of the local elite.

But how far up the Roman social ladder did his connections reach? He was not blessed with an imperial letter of praise because such a letter would undoubtedly have been included in the dossier. There is evidence, in fact, that Trajan, the then reigning emperor, would not agree that Salutaris was as

75. IEph 7.1 3027, in Latin and Greek. We do not know where these inscriptions originally stood. On IEph 7.13027 we have no relevant information: "Zwei aneinander passende Fragmente eines unprofilierten Basismittelstückes aus bläulichem Marmor, die linke obere Ecke bildend”, "(Keil) Skizzenbuch 1851"; IEph 3620 was found in secondary use: "Verbaut in der Scholasticiatherme".

76. Probably, because the word amicus is supplied in IEPh 7.1 3027, 1. 5.

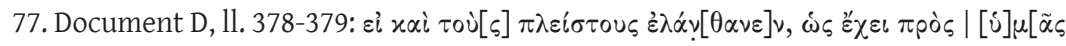

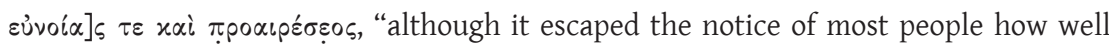
disposed (...)". 
important to Ephesos as Flavianus writes. ${ }^{78}$ By lucky coincidence, we possess a letter by Trajan addressing Pliny the Younger (10.117), in which the emper-

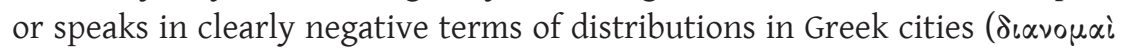
is written in Greek: "in speciem $\delta \iota \alpha \nu \mu \tilde{n} s$ "), especially when large numbers of people and entire groups (or bodies: "quasi per corpora"), as opposed to single individuals, were invited to them. No wonder Salutaris' lotteries among the members of all Ephesian tribes were abolished a few years later.

Salutaris' fame most likely did not reach the emperor and his circle, but it is a safe guess that his foundation put his name in everybody's mouth at Ephesos. If some Ephesians did not visit the theatre on a regular basis to admire his inscriptions, they could not fail to notice the processions in the streets of Ephesos every couple of weeks. And at least one person at Ephesos was not saying good things about him. That persons' voice survived the centuries thanks to two graffiti scribbled on the walls of a house at Ephesos. ${ }^{79}$ One texts reads:

$$
\begin{aligned}
& \text { Salutaris | cun(n)um li(n)ge | Libetr(a)e } \\
& \text { "Salutaris lick the vulva of Libetra!" }
\end{aligned}
$$

Another is similarly explicit in connection with boys. ${ }^{80}$

Mainly on account of these graffiti, the excavators have tentatively suggested that that building was Salutaris' residence at Ephesos. ${ }^{81}$ It is doubtful, however, that the graffiti offer evidence for anything beyond the fact that Salutaris was unpopular with someone. It would come as no surprise if some Ephesians were displeased to have been deprived of a share in Salutaris' distributions because that money was re-directed to creating 20 more statues and 20 more bases with Salutaris' name on them. Others may have been displeased to see the city streets blocked frequently with processions. Still others may have perceived the small sculptures as objects in repeated crowning ceremonies of the multiple epigraphic copies of Salutaris' cursus honorum at the theatre. Instead of speculating further, however, I want to suggest a few reasons why we should not regard this great inscription as clear evidence of a great benefaction.

78. And there is no good evidence that Trajan had a personal connection to Salutaris, despite van Tilborg 1996, 179 and Rathmayr 2006, 12.

79. Taeuber 2005, 349-350; Taeuber 2010, 472 (no. GR 146).

80. Taeuber 2005, 350-351; cf. Taeuber 2010, 473 (no. GR 149).

81. Taeuber 2005, 351-352; Rathmayr 2006, 123-124; Taeuber 2010, 472. 
Another letter in the correspondence between Pliny and Trajan (10.110) raises doubts about the size of Salutaris' donations to Ephesos. In that letter, a euergetes is said to have received from his native city, Amisos in Pontos, a gift of 40,000 denarii in recognition of donations that he had made to his city earlier. It follows that the man's donations to Amisos must have been at least as high as the sum that the city returned to him in appreciation of his services. Compare Amisos with Ephesos, in size, wealth and importance, and Salutaris' 20,000 denarii cease to impress. Nor in fact is that sum impressive compared to the sums donated in support of building projects by benefactors of roughly the same date in Asia Minor. Opramoas of tiny Rhodiapolis donated over one million denarii. ${ }^{82}$ And Opramoas was probably a small player in the league of euergetai, at least compared with distinguished members of the imperial elite. At Ephesos, the Vedii, active some three decades later than Salutaris, donated entire buildings. ${ }^{83}$

Add to this the fact that Salutaris did not intend to part with the donated capital; that the statues that would be carried in his processions were in fact statuettes; and that he donated two sculptures that he probably already owned, and intended to keep until he died, and we may have reason to conclude that his 29 inscriptions in the theatre bestowed disproportionately great honor on the founder of those processions, distributions, and lotteries.

\section{Salutaris' imitatio Plutarchi}

C. Vibious Salutaris' donations to Ephesos were therefore not exceptionally generous but were nevertheless rewarded with what were arguably over-generous honors. That his foundation was commemorated in a large epigraphic monument, probably has something to do with his personal connection to Roman provincial administrators. But perhaps not entirely. Another reason why Salutaris' idiosyncratic interpretation of Greek euergetism was, to some extend at least, received favourably at Ephesos, may, again, be connected to his Roman background, but in a different way. Salutaris was no senator at Rome, but he had become a member of the city council at Ephesos. In that position he favoured, and promoted, a hybrid identity for his host city. His foundation established a recurring ritual propagation of a Graeco-Roman Ephesos, one that

82. Kokkinia 2000.

83. Steskal et al. 2008. 
found supporters among the numerous Romans and Rome-friendly Greeks of Ephesos. In particular, Salutaris' stroke of genius in pairing the Roman ordo equester with the ephebeia, something that could have come from the quill of the best-selling author of the time, Plutarch, together with the prominent role of the ephebes in his processions, must have been well received among the majority of rich Ephesians who were primarily traders and financiers, like Salutaris himself -as opposed to land-owners- and members of the same order as he, if they were Roman. ${ }^{84}$

In contrast to what has been argued in the past, I want to suggest that it was this quality of Salutaris' foundation, that is, its clear affirmation of Ephesos' attachment to Rome, that won it enough support to overcome the fact that Ephesos, certainly, had seen more prominent benefactors.

\section{Appendix}

Eix心̀v and $\dot{\pi} \pi \varepsilon \iota x o ́ v \iota \sigma \mu \alpha$ in the Salutaris dossier

'A $\pi \varepsilon\left\llcorner x^{\prime} v\llcorner\sigma \mu \alpha\right.$ in the Salutaris dossier usually means a sculpture representing the goddess Artemis. Eixóves, on the other hand, are usually all other sculptures donated by Salutaris, including the portraits of the emperor and the personifications of civic bodies, both Roman and Ephesian. In document $G$, however, Salutaris makes an additional donation of two sculptures, each one

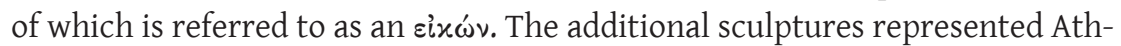
ena Pammousos and Sebaste Homonoia. Consequently, in document G, both a statue of a goddess and a representation of a (deified) abstract idea are called

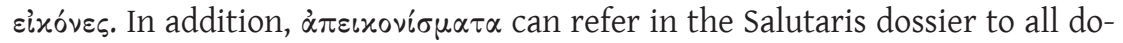
nated sculptures taken together: see 1.317, 1. 438 and 1.540. These variations

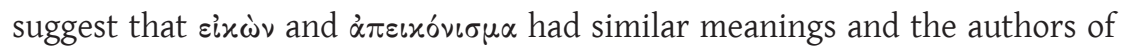
the documents of this dossier used them interchangeably. Scholars, however, have suggested very different interpretations of the two words. Hicks thought that the term sixìv was used "for the representation of abstract ideas", for example the boule, but also Athena Pammousos "as the patroness of the general

84. Pleket 1994 underlines the importance of non-agrarian activities in the Ephesian economy. On the ephebes being associated with horse-riding, see Pleket 2012 (contra Hin 2007). Guettel Cole 1993, 590, points out that the Athenian ephebes, too, carried in procession a divine image, that of Dionysos, from a sanctuary to the city for the festival of the Dionysia. 
education of the young", whereas $\alpha \pi \varepsilon \iota x o ́ v \iota \sigma \mu \alpha$ described "a copy of a recognized type, e.g. a representation of Artemis". ${ }^{85}$ Rogers notes, rightly, that Hicks' interpretation is not supported by the list of images in the Salutaris dossier, which includes Trajan and Plotina.$^{86}$ Rather, says Rogers, "an eikon was usually an honorific image placed in a square or other public place, ${ }^{87}$ but also could be associated with the agalma of the main deity of a temple". 'A $\gamma \alpha \lambda \mu \alpha$, however, is nowhere attested in the Salutaris dossier. The various Greek statue terms have been studied extensively. ${ }^{88}$ The evidence of the Salutaris dossier could contribute to this discussion the observation that, at Ephesos of the 2nd centu-

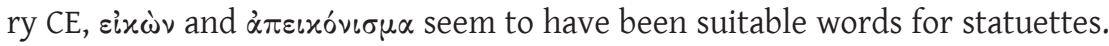
Possibly, $\alpha \dot{\gamma} \alpha \lambda \mu \alpha$ would have suggested a larger sculpture.

\author{
Christina Kokkinia \\ Institute of Historical Research \\ National Hellenic Research Foundation (Athens) \\ kokkinia@eie.gr
}

85. Hicks 1890, 135. Based on Hicks' interpretation, Oliver coined the term “type-statue"; Oliver 1941, 70 and passim.

86. Rogers 1991, 117 n. 15.

87. This is a direct quote from Price $1984,177$.

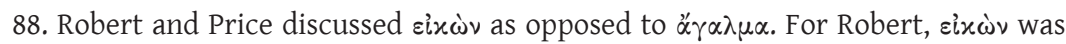
usually an honorific statue or bust of the emperor (Robert 1960, 317-320; see esp. 317:

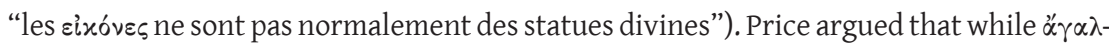
$\mu \alpha$ belonged in a temple and had strong religious connotations, sixìv usually belonged in a non-religious architectural context (Price 1984, 177). Koonce 1988, however, shows that agalma could represent a mortal as well and could be placed in a public square. For recent discussions, see Biard 2017, 54-55, for the term sixóvıov, and Keesling 2017, both with previous bibliography. Keesling is concerned with $\dot{\alpha} \nu \delta \rho \dot{\alpha} \varsigma$ and the development of

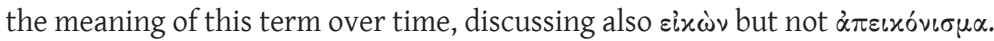




\section{Summary}

Based on a close study of the text of the epigraphic dossier IEph 1a 27, dated $104 \mathrm{CE}$, that once covered an entire wall at Ephesos' theatre and is now in the British Museum and, in addition, on the evidence of other inscriptions relating to C. Vibius Salutaris, this paper argues that: contrary to a widely held view, Salutaris was not an Ephesian by birth; that the terms of his foundation gave him absolute control over the foundation's capital; that the objects donated and the rituals in which they featured were so designed as to bestow disproportionately great honor on the founder. Salutaris' interpretation of euergetism was unconventional and his gifts to Ephesos would most likely have sunk in oblivion, were it not for his connections to representatives of the Roman state, and, most importantly, for his foundation's successful advertising of Ephesos' attachment to Rome. 


\section{Abbreviations - Bibliography}

Ameling, W. 1993. Rev. of Rogers 1991, in HZ 257, 724-726.

Bauer, E. 2014. Gerusien in den Poleis Kleinasiens in hellenistischer Zeit und der römischen Kaiserzeit. Die Beispiele Ephesos, Pamphylien und Pisidien, Aphrodisias und Iasos. Munich.

Biard, G. 2017. La représentation honorifique dans les cités grecques aux époques classique et hellénistique (Bibliothèque des Écoles françaises d' Athènes et de Rome 376). Athens.

Boak, A.E.R. 1915. "The Roman Magistri in the Civil and Military Service of the Empire", HarvStClPhil 26, 73-164.

Bresson, A. 2014. "Le change à Délos et la question du kollybos", BCH 138, 515533.

Brunt, P.A. 1990. Roman Imperial Themes. Oxford.

Burkhalter, F. (ed.) 2014. "Allagè et kollybos. Le change dans l'économie antique", Dossier édité par F. Burkhalter, BCH 138, 511-598.

Dessau, H. 1910. "Die Herkunft der Offiziere und Beamten des römischen Kaiserreichs während der ersten zwei Jahrh. seines Bestehens”, Hermes 45, 1-26.

Devijver, H. 1977. Prosopographia militiarum equestrium quae fuerunt ab Augusto ad Gallienum. Pars Secunda: Litterae L-V (Symbolae Facultatis Litterarum et Philosophiae Lovaniensis, Series A, 3). Leuven.

Devijver, H. 1986. "Equestrian Officers from the East", in P. Freeman, D. Kennedy (eds.), The Defence of the Roman and Byzantine East. Proceedings of a Colloquium Held at the University of Sheffield in April 1986 (British Institute of Archaeology at Ankara Monograph 8; BAR International Series 297). Oxford, 109-225.

Duncan-Jones, R. 2016. Power and Privilege in Roman Society. Cambridge.

Eck, W. 1982. "Jahres- und Provinzialfasten der senatorischen Statthalter von 69/70 bis 138/139 (Teil 1)”, Chiron 12, 281-362.

Eck, W. 1997. "Die nichtsenatorische Administration; Ausbau und Differenzierung”, in W. Eck (ed.), Die Verwaltung des römischen Reiches in der hohen Kaiserzeit. Ausgewählte und erweiterte Beiträge, II (Arbeiten zur römischen Epigraphik und Altertumskunde 3). Basel, 67-106.

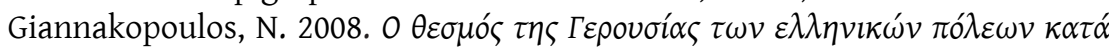

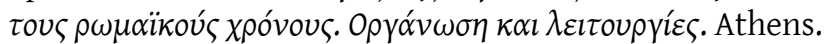

Graf, F. 2015. Roman Festivals in the Greek East. From the Early Empire to the Middle Byzantine Era. Cambridge.

Guettel Cole, S. 1993. Rev. of Rogers 1991, in AJA 97, 589-590.

Hanslik, R. 1958. “Vibius”, RE II.16, cols. 1982-1983. 
Heberdey, R. 1912. Das Theater von Ephesos (Forschungen in Ephesos 2). Vienna. Hicks, E.L. 1890. The Collection of Greek Inscriptions in the British Museum, III. London.

Hin, S. 2007. "Class and Society in the Cities of the Greek East: Education during the Ephebeia", AncSoc 37, 141-166.

Hoskins Walbank, M.E. 1994. Rev. of Rogers 1991, in Phoenix 48, 89-91.

IAph2007. Reynolds, J., Roueché, C., Bodard, G. (eds.), Inscriptions of Aphrodisias (2007) (http://insaph.kcl.ac.uk/iaph2007).

I.Didyma. Rehm, A. 1958. Didyma II. Die Inschriften. Berlin.

IEph 1a. Wankel, H. (ed.) 1979. Die Inschriften von Ephesos. Teil Ia (Inschriften griechischer Städte aus Kleinasien 11.1). Bonn.

IEph 3. Engelmann, H., Knibbe, D. Merkelbach, R. (eds.) 1980. Die Inschriften von Ephesos. Teil III (Inschriften griechischer Städte aus Kleinasien 13). Bonn.

IEph 7.1. Meriç, R., Merkelbach, R., Nollé, J., Şahin, S. (eds.) 1981. Die Inschriften von Ephesos. Teil VII.1 (Inschriften griechischer Städte aus Kleinasien 17.1). Bonn.

IKibyra. Corsten, Th. (ed.) 2002. Die Inschriften von Kibyra. Teil I: Die Inschriften der Stadt und ihrer näheren Umgebung (Inschriften griechischer Städte aus Kleinasien 60). Bonn.

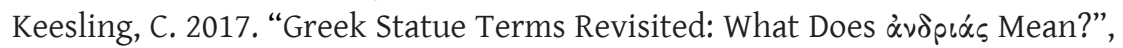
GRBS 57, 837-861.

Kirbihler, F. 2007. "Die Italiker in Kleinasien, mit besonderer Berücksichtigung von Ephesus (133 v. Chr. - 1.Jh. n. Chr.)”, in M. Meyer (ed.), Neue Zeiten - Neue Sitten. Zu Rezeption und Integration römischen und italischen Kulturguts in Kleinasien. Wien, 19-35.

Kirbihler, F. 2016. Des Grecs et des Italiens à Éphèse: histoire d'une intégration croisée: 133 a.C. - 48 p.C. Bordeaux.

Kokkinia, Ch. 2000. Die Opramoas-Inschrift von Rhodiapolis. Euergetismus und Soziale Elite in Lykien. Bonn.

Kokkinia, Ch. 2009. "The Role of Individuals in Inscribing Roman State Documents: Governors' Letters and Edicts”, in R. Haensch (ed.), Selbstdarstellung und Kommunikation. Die Veröffentlichung staatlicher Urkunden auf Stein und Bronze in der Römischen Welt. Munich, 191-206.

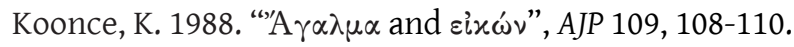

Kunnert, U. 2012. Bürger unter sich. Phylen in den Städten des kaiserzeitlichen Ostens. Basel.

Lahusen, G. 1999. "Zu römischen Statuen und Bildnissen aus Gold und Silber”, ZPE 128, 251-266. 
MacMullen, R. 2014. Why Do We Do What We Do? Motivation in History and the Social Sciences. Berlin.

Madigan, B. 2013. The Ceremonial Sculptures of the Roman Gods. Leiden.

Marshall, F.H. 1916. The Collection of Greek Inscriptions in the British Museum, IV. Section II: Supplementary and Miscellaneous Inscriptions. London.

Melville Jones, J.R. 1971. "Denarii, Asses and Assaria in the Early Roman Empire”, BICS 18, 99-105.

Naour, Ch. 1977. "Inscriptions de Lycie”, ZPE 24, 265-290.

Ng, D.Y. 2018. "The Salutaris Foundation. Monumentality through Periodic Rehearsal", in B. Longfellow, E. Perry (eds.), Roman Artists, Patrons, and Public Consumption: Familiar Works Reconsidered. Ann Arbor, 63-87.

Nicolet, C. 1991. “Frumentum mancipale' en Sicile et ailleurs”, in A. Giovannini (ed.), Nourrir la plèbe. Actes du colloque tenu à Genève les 28 et 29 IX. 1989 en hommage à Denis van Berchem (Schweizeriche Beiträge zur Altertumswissenschaft 22). Basel, 119-141.

Oliver, J.H. 1941. The Sacred Gerusia (Hesperia Suppl. 6). Baltimore.

Pleket, H. 1994. "The Roman State and the Economy: the Case of Ephesos", in J. Andreau, P. Briant, R. Descat (eds.), Économie antique. Les échanges dans l'antiquité: le rôle de l'état. Saint-Bertrand-de-Comminges, 115-126.

Pleket, H. 2012. "Ephebes and Horses", Mnemosyne 65, 324-328.

Price, S. 1984. Rituals and Power. The Roman Imperial Cult in Asia Minor, Cambridge.

Quaß, F. 1982. “Zur politischen Tätigkeit der munizipalen Aristokratie des griechischen Ostens in der Kaiserzeit”, Historia 31, 188-213.

Rathmayr, E. 2006. "Götter und Kaiserkult im privaten Wohnbereich anhand von Skulpturen aus dem Hanghaus 2 in Ephesos", Römische Historische Mitteilungen 48, 103-133.

RE. Pauly, A.,Wissowa, G. (eds.), Realenzyklopädie der klassischen Altertumswissenschaft. Stuttgart, 1893-1978.

Robert, L. 1960. "Recherches épigraphiques”, RÉA 62, 276-361.

Rogers, G.M. 1991. The Sacred Identity of Ephesos: Foundation Myths of a Roman City. London.

Rousset, D. 2004. "Épigraphie grecque et géographie historique du monde hellénistique", École pratique des hautes études. Section des sciences historiques et philologiques. Livret-Annuaire 18 (2002-2003).

Schulte, C. 1994. Rev. of Rogers 1991, in Klio 76, 518-521.

Smith, R. 2006. "The Construction of the Past in the Roman Empire", in D.S. Potter (ed.), A Companion to the Roman Empire. Malden MA, 411-438.

Spawforth, A. 1992. Rev. of Rogers 1991, in CR 42, 383-384. 
Steskal, M., La Torre, M., Forstenpointer, G. (eds.) 2008. Das Vediusgymnasium in Ephesos. Archäologie und Baubefund. Vienna.

Taeuber, H. 2005. "Vibius Salutaris. Wohnungsbesitzer im Hanghaus 2?”, in B. Brandt, V. Gassner, S. Ladstätter (eds.), Synergia: Festschrift für Friedrich Krinzinger. Vienna, 349-353.

Taeuber, H. 2010. "Graffiti”, in F. Krinzinger (ed.), Hanghaus 2 in Ephesos. Die Wohneinheit 1 und 2. Baubefund, Ausstattung, Funde, II (Forschungen in Ephesos 8.8). Vienna, 472-477.

Thomasson, B.E. 1984. Laterculi Praesidum, I. Arlöv.

van Bremen, R. 1993. Rev. of Rogers 1991, in JRS 83, 245-246.

van Tilborg, S. 1996. Reading John in Ephesus. Leiden.

Weiss, C.F. 2012. "Bodies in Motion: Civic Ritual and Place-Making in Roman Ephesos", in D.M. Totten, K.L. Samuels (eds.), Making Roman Places, Past and Present: Papers Presented at the First Critical Roman Archaeology Conference Held at Stanford University in March 2008 (JRA Suppl. 89). Portsmouth, Rhode Island, 50-63.

White, M.L. 1995. "Urban Development and Social Change in Imperial Ephesos", in H. Koester (ed.), Ephesos. Metropolis of Asia. An Interdisciplinary Approach to Its Archaeology, Religion, and Culture. Valley Forge, 27-79.

Wood, J.T. 1877. Discoveries at Ephesos. Including the Site and Remains of the Great Temple of Diana. London.

Wörrle, M. 1988. Stadt und Fest im Kaiserzeitlichen Kleinasien. Munich. 


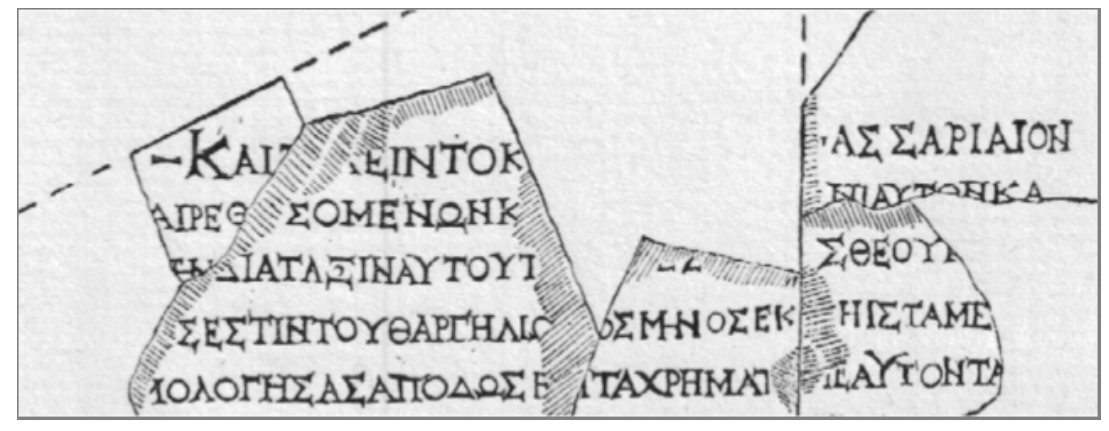

Fig. 1. Heberdey 1912, facsimile of the Salutaris inscription (detail; 11. 66-70). 